\title{
Direct hypothalamic and indirect trans-pallidal, trans-thalamic, or trans-septal control of accumbens signaling and their roles in food intake
}

\author{
Kevin R. Urstadt ${ }^{1 *}$ and B. Glenn Stanley ${ }^{2}$ \\ ' Department of Psychology, University of Michigan, Ann Arbor, MI, USA \\ ${ }^{2}$ Departments of Psychology and Cell Biology and Neuroscience, University of California - Riverside, Riverside, CA, USA
}

\section{Edited by:}

Arshad M. Khan, University of Texas at EI Paso, USA

Reviewed by:

Richard H. Thompson, University of Southern California, USA

Brian A. Baldo, University of

Wisconsin-Madison, USA

Gorica Petrovich, Boston

College, USA

Sindy Cole, Boston College, USA

\section{*Correspondence:}

Kevin R. Urstadt, Department of Psychology, University of Michigan, 1012 East Hall, 530 Church Street, Ann Arbor, MI 48109, USA

e-mail: kurst001@gmail.com
Due in part to the increasing incidence of obesity in developed nations, recent research aims to elucidate neural circuits that motivate humans to overeat. Earlier research has described how the nucleus accumbens shell (AcbSh) motivates organisms to feed by activating neuronal populations in the lateral hypothalamus (LH). However, more recent research suggests that the LH may in turn communicate with the AcbSh, both directly and indirectly, to re-tune the motivation to consume foods with homeostatic and food-related sensory signals. Here, we discuss the functional and anatomical evidence for an LH to AcbSh connection and its role in eating behaviors. The LH appears to modulate Acb activity directly, using neurotransmitters such as hypocretin/orexin or melanin concentrating hormone (MCH). The LH also indirectly regulates AcbSh activity through certain subcortical "relay" regions, such as the lateral septum (LS), ventral pallidum (VP), and paraventricular thalamus, using a variety of neurotransmitters. This review aims to summarize studies on these topics and outline a model by which LH circuits processing energy balance can modulate AcbSh neural activity to regulate feeding behavior.

\section{Keywords: accumbens, septum, paraventricular thalamus, ventral pallidum, lateral hypothalamus, eating}

\section{INTRODUCTION}

\section{THE LATERAL HYPOTHALAMUS}

The rise in obesity rates in the U.S. (Flegal et al., 2002) and other developed nations has made an urgent case for research to unravel the brain's regulation of hunger and motivation to conume foods. Through this research, various brain areas have been implicated in food intake control. One area that has received much focus in this field is the lateral hypothalamus ( $\mathrm{LH})$. Once dubbed the "hunger center" of the brain, the LH has since been characterized as a signal-integrating hub for diverse neural inputs that regulate its output - the initiation of food procurement and consumption (Wise, 2013).

Many functional studies of the LH have revealed its impact on feeding. For instance, electrical stimulation of the LH elicits intake (Wyrwicka and Dobrzecka, 1960), while electrolytic lesions of the LH induce aphagia (Winn et al., 1984). Electrophysiological monitoring of $\mathrm{LH}$ neurons during certain food-related activities provides additional insight for the LH's role in integrating foodrelated sensory information. $\mathrm{LH}$ neurons change firing rates to visual food cues (Mora et al., 1979) and to decreases in blood glucose (Oomura et al., 1974), while eating reverses such changes in firing rates (Mora et al., 1979). This collection of evidence highlights the LH's role in feeding behaviors.

Various behavioral studies have delineated subdivisions of the LH into distinct feeding-regulating ensembles. These subdivisions include the perifornical area (pfLH; Leibowitz and Rossakis, 1978), the area lateral to the fornix and adjacent to the internal capsule/cerebral peduncle (lLH; Stanley et al., 1993a), and the area ventrolateral to the fornix and adjacent to the optic tract (vlLH) (Baldo et al., 2004). The pharmacological underpinnings of food intake control via the pfLH and the lLH are well-established. The $1 \mathrm{LH}$ is particularly receptive to primary amino acid neurotransmitters; injection of glutamate, glutamate agonists, or $\mathrm{GABA}_{\mathrm{A}}$ receptor antagonists specifically induces feeding (Stanley et al., 1993a; Duva et al., 2002; Turenius et al., 2009a,b; Charles et al., 2014). Also, microdialysis within the ILH reveals increased synaptic glutamate and decreased synaptic GABA prior to onset of a meal, while the reverse occurs prior to cessation of a meal (Rada et al., 1997). Thus, a balancing of synaptic glutamate and GABA input to $1 \mathrm{LH}$ neurons is utilized to direct feeding in a minute-by-minute fashion (Stanley et al., 2011). The pfLH is a locus through which NPY, norepinephrine, and dopamine regulate food intake (Leibowitz and Rossakis, 1978, 1979; Stanley et al., 1993b) in addition to other neurotransmitters (for review, see Meister, 2007). The behavioral effects of vlLH manipulations are not well characterized. Though functional studies support these three general LH subdivisions, anatomical evidence further subdivides these areas into numerous smaller regions that may also be functionally distinct (Swanson, 2004; Swanson et al., 2005).

The $\mathrm{LH}$ also regulates effort to procure food rewards. Two neuron groups in particular, the orexin and the melanin concentrating hormone $(\mathrm{MCH})$ neurons, are distributed 
throughout the LH (Hahn, 2010) and mediate consumption and/or food-directed effort-based actions. ICV injection of orexin or MCH induces food intake (Rossi et al., 1999; Zhu et al., 2002). Orexin neurons are activated by contexts associated with food rewards. Such contexts feature either sweet foods for satiated rats or regular chow for food-deprived rats (Harris et al., 2005; Choi et al., 2010). Further, ICV injection of orexin increases progressive ratio responding breakpoints for palatable food rewards, whereas injection of its antagonist decreases this breakpoint (Choi et al., 2010). In a related manner, $\mathrm{MCH}$ directs reward-motivated behaviors. $\mathrm{MCH}$ knockout mice and wild type mice given an $\mathrm{MCH}$ antagonist display impairments in selectively responding to reward-associated cues, showing how $\mathrm{MCH}$ inhibits generalization of responses to non-rewarding stimuli (Sherwood et al., 2012). It should be noted that unlike orexin, $\mathrm{MCH}$ originates from extrahypothalamic areas such as the basal forebrain and pons (Bittencourt et al., 1992). Thus, it is unclear how these other $\mathrm{MCH}$ groups contribute to behaviors manifested by ICV $\mathrm{MCH}$ injections. Nonetheless, orexin and $\mathrm{MCH}$ can regulate both feeding and food reward procurement in complimentary ways.

LH innervation of mesolimbic circuitry serves to integrate homeostatic information with motivation to procure foods and the valuation of food tastes. Indeed, food deprivation increases "liking" responses while caloric satiety decreases them (Berridge, 1991). Also, ablation or inhibition of the anterior LH will suppress "liking" responses to sucrose and reduce food intake (Ho and Berridge, 2014). LH orexin neurons are one likely candidate population that may at least modulate some of these effects. Orexin neurons are activated by deficits in available glucose (Nishimura et al., 2014) as well as by food restriction (Kurose et al., 2002), and are inhibited by direct application of glucose (Burdakov and González, 2009) and leptin (Yamanaka et al., 2003). Aside from direct effects on orexin neurons by circulating factors (Hâkansson et al., 1998; Burdakov and González, 2009; Qi et al., 2010), some effects may be mediated indirectly via the arcuate nucleus and its peptides (Zheng et al., 2002), via long-form leptin receptorpossessing (LepRb) neuron innervation of orexin neurons (Louis et al., 2010), and/or via direct action of leptin on orexin neurons.

\section{THE NUCLEUS ACCUMBENS SHELL}

Another brain region, the nucleus accumbens, is most typically associated with hedonia and motivation (Broekkamp et al., 1975; Kelley et al., 2002) yet also regulates the conversion of motivation into goal-directed actions (Mogenson et al., 1980). Rats selfstimulate when an electrode is implanted into the accumbens (Schaefer and Michael, 1992). Accumbens neurons can fire to the receipt of a reward or in reward-associated contexts (Apicella et al., 1991a,b), and some accumbens neurons produce action potentials in anticipation of a reward (Schultz et al., 1992). Activation of accumbens neurons also occurs in animals reexposed to drugs of abuse after withdrawal and abstinence (Todtenkopf et al., 2002). Further, the accumbens innervates components of the basal ganglia (Mogenson et al., 1983), and alterations in accumbens activity change exploratory behaviors (Mogenson and Nielsen, 1984), implicating this area in initiation of goal-directed actions. These are a select few of many studies implicating this region in reward perception and motivated behaviors.

However, the accumbens also regulates feeding, particularly through the accumbens shell (AcbSh) subregion. Lesioning the AcbSh increases food intake, while AcbSh stimulation decreases it (Ramaswamy et al., 1998; van der Plasse et al., 2012). Activation of AcbSh GABA, mu opioid, or $\delta$ opioid receptors, or blockade of AcbSh AMPA receptors, induces feeding specifically (Maldonado-Irizarry et al., 1995; Stratford and Kelley, 1997; Stratford et al., 1998; Castro and Berridge, 2014a). Also, AcbSh neurons pause firing prior to initiation of drinking sucrose solution (Krause et al., 2010), synaptic glutamate levels within the AcbSh decrease during onset of eating (Rada et al., 1997), and AcbSh neurons are activated by contexts associated with palatable meal availability (Park and Carr, 1998). Further, rats recently fed to satiety show reduced expression of preproenkephalin within the AcbSh, signifying a decrease in intra-AcbSh synthesis of the mu opioid receptor (MOR) ligand enkephalin (Will et al., 2007). These data indicate a role for the AcbSh in controlling feeding behaviors.

Glutamate, GABA, and opioid neurotransmission in the AcbSh does not solely affect food intake, but instead acts on the motivation to procure food, the motivation to eat food, and/or hedonic valuation of foods. AcbSh $\mathrm{GABA}_{\mathrm{A}}$ receptor activation or MOR activation increases operant responding for food reward (Wirtshafter and Stratford, 2010; Stratford and Wirtshafter, 2012a), suggesting that these receptors govern the motivation to procure foods. Although AcbSh AMPA receptor blockade does not affect progressive ratio responding breakpoint for food reward, AMPA receptor activation decreases this breakpoint (Mena et al., 2013), suggesting that AcbSh glutamate negatively modulates food-directed efforts. Altering activity of each of these receptors within the AcbSh influences food intake in satiated rats (Maldonado-Irizarry et al., 1995; Stratford and Kelley, 1997; Zhang et al., 1998), demonstrating the roles of these receptors in the motivation to consume foods. However, these receptors have dissociable roles in modulating the rewarding value of foods. Specifically, $G_{A B A}$ or opioid receptor activation increases hedonic value of foods (Peciña and Berridge, 2005; Castro and Berridge, 2014a), whereas AMPA receptor blockade does not (Faure et al., 2010).

Interestingly, these motivational and hedonic effects differ between anterior and posterior AcbSh subregions (aAcbSh and pAcbSh). Activation of $\mathrm{GABA}_{\mathrm{A}}$ receptors within the aAcbSh will increase food consumption and "liking" reactions to sweet tastes. In contrast, $\mathrm{GABA}_{\mathrm{A}}$ receptor activation within the pAcbSh will reduce food intake, suppress "liking" reactions to sweet tastes, and increase aversive responses to bitter tastes (Reynolds and Berridge, 2001, 2002; Faure et al., 2010). Opioid receptor activation within the aAcbSh or the pAcbSh alters hedonic responses to sweet taste similarly to $\mathrm{GABA}_{\mathrm{A}}$ receptor activation, though food intake effects differ between opioid receptor subtypes (Castro and Berridge, 2014a). 
In a complimentary manner, AMPA receptor blockade in the aAcbSh increases food intake while in the pAcbSh such blockade decreases intake, though no effects on "liking" or "disliking" are observed from this manipulation (Faure et al., 2010). However, the testing environment can re-adjust this rostrocaudal difference in AcbSh behavioral control. In a normal testing environment, aAcbSh and pAcbSh DNQX administrations produce appetitive and avoidance behaviors, respectively. Testing in the quiet, dark, familiar home cage causes DNQX injections to all but the caudal $10 \%$ of the AcbSh to induce appetitive behaviors, whereas testing in a noisy, bright, unfamiliar environment causes DNQX injections to all but the rostral $10 \%$ of the AcbSh to induce aversive behaviors (Reynolds and Berridge, 2008). Thus, environmental stressors can "re-tune" the AcbSh AMPA receptormediated neuroanatomical sites governing appetitive and aversive behaviors.

Another intriguing finding is that blockade of metabotropic glutamate receptors 2 and 3 (mGluR2/3) in most of the AcbSh suppresses food intake and hedonic reactions to sucrose while increasing defensive treading and aversive reactions to sucrose (Richard and Berridge, 2011). As AcbSh mGluR2/3 activation decreases extracellular glutamate and mGluR2/3 blockade increases it (Xi et al., 2002), mGluR2/3 function as a pre-synaptic "brake" on glutamate release into the AcbSh. Considering these data, increased glutamate efflux to both the aAcbSh and pAcbSh can blunt motivation to consume food and can reverse tastes from palatable to aversive. Indeed, activation of AcbSh AMPA receptors decreases sucrose intake (Stratford et al., 1998). In contrast, decreased glutamate input to the AcbSh (mimicked by AMPA receptor blockade) only acts on motivation to eat, and does so in a neuroanatomically "fluid" manner dependent on the presence of environmental stressors.

In summary, GABA and opioid neurotransmissions to the AcbSh regulate food directed effort, the motivation to eat, and the hedonic and aversive properties of food tastes. These neurotransmitters perform these behavioral functions oppositely within the aAcbSh vs. the pAcbSh. Hedonic and motivational effects of glutamate neurotransmission to the AcbSh are more nuanced. Excess glutamate neurotransmission to most of the AcbSh hinders motivation to procure and to consume food and reverses hedonic perception of sweet tastes to aversive. In contrast, decreased AcbSh glutamate input acts to alter "wanting" without altering "liking". Stressors substantially alter which AcbSh subregions, in response to decreased glutamate, produce appetitive vs. avoidance behaviors. These changes in the motivation to eat and the rewarding value of foods are transmitted to downstream behavioral effector regions, including the LH.

\section{DESCENDING AcbSh TO LH CIRCUITS}

Anatomical evidence reveals a direct projection from the AcbSh to the LH (Usuda et al., 1998; Duva et al., 2005). In particular, the dorsomedial aAcbSh "hedonic hotspot" projects strongly to the anterior vlLH and the pfLH, likely innervating orexin neurons, whereas the ventromedial aAcbSh projects predominantly to the ILH (Yoshida et al., 2006; Thompson and Swanson, 2010; Zahm et al., 2013). Thus, the aAcbSh "hotspot" is poised to regulate hedonic value of tastes through pfLH orexin neurons, while the ventromedial aAcbSh likely drives food intake through the primary amino acid neurotransmittersensitive lLH.

Multiple functional studies support this AcbSh to LH circuit model. AcbSh GABA- or glutamate-mediated feeding is suppressed or halted by pharmacological inhibition of the LH (Maldonado-Irizarry et al., 1995; Stratford and Kelley, 1999) or by LH lesions (Stratford and Wirtshafter, 2012b). Further, unilateral LH lesions or unilateral lLH inhibition reduces AcbSh feeding in a behaviorally-specific manner (Stratford and Wirtshafter, 2012b; Urstadt et al., 2013a,b). Indeed, feeding induced by unilateral AcbSh AMPA receptor blockade with DNQX is suppressed by NMDA receptor blockade of the ipsilateral but not contralateral LH (Figure 1), demonstrating that unilateral LH inhibition specifically suppresses AcbSh mediated feeding. As the projection neurons of the AcbSh are primarily GABAergic (Oertel and Mugnaini, 1984), some suggest AcbSh inhibition disinhibits the LH, allowing for feeding to occur (Kelley et al., 2005a) and increasing motivation to procure foods (Wirtshafter and Stratford, 2010). aAcbSh inhibition with muscimol results in increased c-fos expression in the pfLH, ILH, and vlLH subregions (Stratford, 2005), and particularly in orexin neurons but not in $\mathrm{MCH}$ neurons (Zheng et al., 2003; Baldo et al., 2004). Based on these data, AcbSh-mediated feeding is regulated through multiple LH subregions.

Some recent data implicates the ventral pallidum (VP) as an indirect route for AcbSh to $\mathrm{LH}$ signaling in the control of food intake. Anterograde tracing studies have shown that

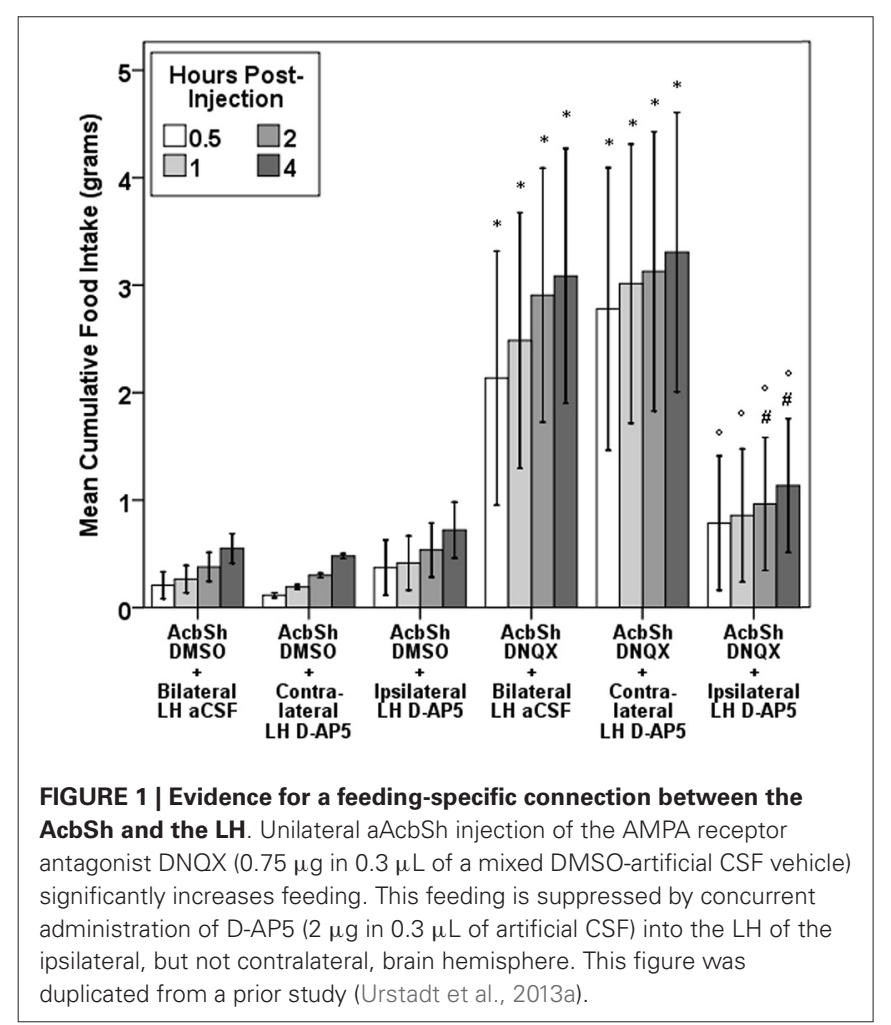


the AcbSh projects to the medial VP (Usuda et al., 1998) and the medial VP in turn projects to the LH (Groenewegen et al., 1993). Functional evidence measuring food intake also supports a model of this three-part circuit. Feeding elicited by unilateral AcbSh muscimol injection is halted by excitotoxic lesion of the ipsilateral VP or the ipsilateral LH (Stratford and Wirtshafter, 2012b). Also, unilateral AcbSh muscimol induces c-fos expression in both the ipsilateral VP and the ipsilateral LH (Stratford, 2005). How this indirect AcbSh-VP-LH circuit operates in parallel with the direct AcbSh to $\mathrm{LH}$ circuit to control feeding remains unclear. Also, the neurotransmitters used in this three-part circuit are only partly described; AcbSh projections are GABAergic (Oertel and Mugnaini, 1984), but the VP may secrete either GABA or acetylcholine (Walaas and Fonnum, 1979) and opioid co-transmitters (Harlan et al., 1987) to the $\mathrm{LH}$.

\section{DIRECT ASCENDING PATHWAY FROM LH TO AcbSh}

Evidence for a direct $\mathrm{LH}$ to AcbSh projection also exists. Early retrograde tracing studies using AcbSh injections of Fluorogold or wheat germ agglutinin revealed AcbSh-projecting neurons in the pfLH, ILH, and vlLH (Phillipson and Griffiths, 1985; Brog et al., 1993). Moderate numbers of retrogradelylabeled neurons were observed within the pfLH and ILH after injections in either the medial aAcbSh or the medial pAcbSh. In contrast, numerous vlLH neurons were labeled by pAcbSh tracer injections while few were labeled by aAcbSh injections. These anatomical findings suggest that two distinct LH populations differentially innervate the AcbSh, one arising from the pfLH and $\mathrm{ILH}$, the other from the vlLH.

Due to differences in the neurotransmitters used by each subregion, the pfLH/lLH and the vlLH differently regulate AcbSh activity. The pfLH and $1 \mathrm{LH}$ secrete a myriad of peptide neurotransmitters in addition to orexins and $\mathrm{MCH}$, which include but are not limited to dynorphin, enkephalin, cocaine and amphetamine regulated transcript (CART), nesfatin-1, corticotropin releasing factor (CRF), neurotensin, and galanin (Skofitsch and Jacobowitz, 1985; Fallon and Leslie, 1986; Broberger, 1999; Watts et al., 1999; Goebel et al., 2009; Hahn, 2010). Retrograde tracing with pseudorabies virus showed that roughly one-third of AcbSh-projecting pfLH and $1 \mathrm{LH}$ neurons contain orexin and one-third contain $\mathrm{MCH}$ (Kampe et al., 2009), leaving the remaining third uncharacterized. Other anatomical work corroborates these pfLH/lLH to AcbSh connections; moderate amounts of receptors for orexin and $\mathrm{MCH}$ are located in the AcbSh as are fibers containing these peptides (Bittencourt et al., 1992; Trivedi et al., 1998; Saito et al., 2001; Baldo et al., 2003). In contrast, the nearby vlLH has far fewer of these peptidergic neuron types, though it contains neurons possessing either vesicular GABA transporter or, to a lesser degree, vesicular glutamate transporter 2 (Vong et al., 2011). In summary, the pfLH and ILH can potently modulate both aAcbSh and pAcbSh activity using peptide neurotransmitters whereas the vlLH can directly regulate pAcbSh activity, but not aAcbSh activity, using glutamate and GABA.
Some functional evidence reveals how the LH may influence food intake and food-directed effort via direct innervation of the AcbSh. Injection of orexin A into the AcbSh will induce feeding and locomotion (Thorpe and Kotz, 2005). Also, as intraaccumbal orexin administration increases phasic dopamine efflux into the AcbSh (Patyal et al., 2012), orexin likely influences movement patterns and potentially motivated behaviors. In contrast, $\mathrm{MCH}$ knockout mice display sensitized dopamine responses via the AcbSh and increased locomotion (Pissios et al., 2008), implying that $\mathrm{MCH}$ normally inhibits certain movement patterns. Interestingly, these mice display increased responding to non-rewarding stimuli in a conditioned reinforcement paradigm (Sherwood et al., 2012), which indicates that $\mathrm{MCH}$ inhibits actions that are not tied to the receipt of rewards such as food. Sherwood et al. (2012) noted that this process may occur via the AcbSh due to $\mathrm{MCH}$ receptor associations with AcbSh dopamine receptors and control over AcbSh neuron excitability (Georgescu et al., 2005; Sears et al., 2010), both of which modulate appetitive responses. Considering that these two peptides are secreted by the LH to the AcbSh, and considering the behavioral effects of orexin and $\mathrm{MCH}$ in the AcbSh, the $\mathrm{LH}$ is poised to differentially regulate food intake and motivated behaviors via the AcbSh.

Numerous other neuropeptides exist in the LH, and some of these neurotransmitters may also directly regulate AcbSh activity and thus food intake. CART frequently co-localizes with $\mathrm{MCH}$ in LH neurons (Broberger, 1999), so CART can be co-transmitted with $\mathrm{MCH}$ to the AcbSh. AcbSh injection of CART decreases both regular and AcbSh muscimol-elicited food intake, and CART mRNA levels are decreased within the medial pfLH during fasting (Yang et al., 2005), suggesting that the pfLH may secrete CART to the AcbSh to suppress feeding. Also, recent evidence shows dynorphin injection into the AcbSh alters the hedonic value of sucrose solution (Castro and Berridge, 2014a), and dynorphin can be co-transmitted to the AcbSh by LH orexin neurons (Chou et al., 2001). These other peptide neurotransmitters secreted by the $\mathrm{LH}$ are poised to regulate feeding and food-seeking behavior via the AcbSh.

AcbSh input of one other neurotransmitter, CRF, has been associated with modulation of food-directed behaviors. Medial pAcbSh CRF microinjections increase cue-triggered operant responding for sucrose, indicating that AcbSh CRF increases incentive salience of cues that predict availability of palatable food (Peciña et al., 2006). This behavioral effect of AcbSh CRF action is likely mediated by increased AcbSh dopamine release (Lemos et al., 2012). However, prior severe stress prevents this CRFmediated dopamine release and decreases appetitive behaviors (Lemos et al., 2012). Further, intra-AcbSh CRF administration also decreases sucrose solution intake in two-bottle tests and increases AcbSh acetylcholine (Chen et al., 2012b). Increased AcbSh acetylcholine has been implicated as a marker of satiety (Mark et al., 1992) and may regulate the avoidance of food or decreased motivation to feed (Hoebel et al., 2007). Also worth noting is that AcbSh CRF injection induces oral stereotypy in the absence of foods or objects to interact with (Holahan et al., 1997). This mechanism implicates AcbSh CRF neurotransmission in orofacial motor pattern control. It is unclear whether these 
AcbSh CRF effects are mediated specifically by LH CRF input, though such input may have feeding suppressive effects. LH CRF neurons are activated by dehydration, and are involved with dehydration-induced anorexia (Watts et al., 1999; de Gortari et al., 2009).

Lastly, the LH transmits glutamate and GABA to the AcbSh. Orexin neurons utilize glutamate as a co-transmitter as they possess vesicular glutamate transporters (Rosin et al., 2003), whereas $\mathrm{MCH}$ neurons express glutamic acid decarboxylase, implicating GABA as their co-transmitter (Elias et al., 2008). LH LepRb neurons could also secrete GABA to the AcbSh (Patterson et al., 2011). Through pfLH and ILH innervation of both the aAcbSh and pAcbSh (Kampe et al., 2009), glutamate via orexin neurons and GABA via $\mathrm{MCH}$ neurons can modulate the effort to consume foods and the hedonic value of foods. In contrast, the vlLH usually secretes glutamate and GABA without orexin or $\mathrm{MCH}$ as co-transmitters. Immunohistochemical and in situ hybridization evidence shows vesicular GABA transporter expression in this region (Vong et al., 2011). Glutamatergic and GABAergic projections arising from the vlLH and terminating in the pAcbSh are poised to directly regulate avoidance and aversive qualities of food (Reynolds and Berridge, 2001, 2002; Faure et al., 2010). Ultimately, each route by which $\mathrm{LH}$ subregions alter activity of the AcbSh and change food intake is subsequently re-directed back through the LH, as ablation or inhibition of the LH halts AcbShmediated feeding (Stratford and Wirtshafter, 2012b; Urstadt et al., 2013a).

\section{INDIRECT LH TO Acb PATHWAYS}

Considering the food-directed motivational and hedonic effects of GABA, glutamate, and peptide neurotransmission within the AcbSh, it is of much interest to determine the extraaccumbal sources of such input. Additionally, identifying the afferents to rostral vs. caudal AcbSh regions reveals how other brain regions differentially regulate the motivation to eat and the rewarding or aversive value of foods. Notable inputs to the AcbSh include glutamatergic efferents from the prefrontal cortex, paraventricular thalamic nucleus (PVT), hippocampus, and amygdala (Walaas and Fonnum, 1980; Christie et al., 1985, 1987; Moga et al., 1995) and subcortical GABAergic efferents from the lateral septum (LS), VP, and ventral tegmental area (Churchill and Kalivas, 1994; Van Bockstaele and Pickel, 1995; Zhao et al., 2013). Various neuropeptides are cotransmitted in these inputs. Importantly, the LH innervates all of these brain regions (Goto et al., 2005; Hahn and Swanson, 2010).

There are many brain regions that indirectly connect the $\mathrm{LH}$ and the AcbSh. However, this review focuses on select subcortical regions that can "relay" signals from the LH to the AcbSh. As much work has already focused on how the VTA is one relay in LH to AcbSh signaling (Sharf et al., 2010), we instead discuss similar intermediary roles for the LS, VP, and PVT. These regions were selected to address their understudied roles in AcbSh-mediated food intake regulation and to highlight recent research that has begun to suggest these roles. These areas possess orexin and $\mathrm{MCH}$ fibers and show expression of receptors for one or both of these neurotransmitters (Bittencourt et al., 1992; Marcus et al., 2001; Saito et al., 2001; Fadel and Deutch, 2002; Baldo et al., 2003), indicating that they receive $\mathrm{LH}$ innervation. Additionally, tract tracing evidence reveals direct projections from the $\mathrm{LH}$ to these three regions (Chen and Su, 1990; Cullinan and Záborszky, 1991; Risold and Swanson, 1997b; Goto et al., 2005; Kirouac et al., 2006; Hahn and Swanson, 2010). Each of these areas projects to the AcbSh. The nuances of these projection patterns, as well as the functional evidence for their roles in relaying information from the LH to the AcbSh to shape feeding behavior, are discussed below.

An important point to note is that in this review we term these intermediate brain regions in the LH to AcbSh circuit as "relays". This term gives an overly simplistic impression of their purpose in food intake regulation. Instead of merely relaying signals between $\mathrm{LH}$ and AcbSh, they integrate and process signals both from the $\mathrm{LH}$ and from their various other afferents. For instance, some authors directly state that the LS had long been referred to as a relay node in affective signaling, whereas it performs far more complex and integrative tasks (Sheehan et al., 2004). For the sake of brevity we refer to these areas as relays, but these regions integrate, process, and transmit other information, such as stress, emotional state, and sensory input, to various other brain areas. Each of these processes can impact food intake.

\section{THE LATERAL SEPTUM}

Similar to the nearby accumbens, the LS contains medium-sized spiny neurons. Interestingly, most LS neurons are projection neurons that also colateralize on other LS neurons, allowing them to regulate intra- and extra-LS signaling (Sheehan et al., 2004). LS neurons are primarily GABAergic (Zhao et al., 2013). The LS is intricately subdivided based on neurotransmitter input; intra-LS compartments are distinguished by intensity of fibers labeled for somatostatin, neurotensin, enkephalins, dopamine beta-hydroxylase, tyrosine hydroxylase, calcitonin gene-related peptide, CRF, and other neurotransmitter markers (Risold and Swanson, 1997a). In particular, the caudal LS, distinguished by heavy somatostatin fiber immunoreactivity, is bidirectionally connected with the LH, whereas the rostral LS and ventral LS are bidirectionally connected with medial and anterior hypothalamic sites, respectively (Risold and Swanson, 1997b).

The LS is typically associated with fear and defensive reactions, as manipulations of the LS modify behaviors to fearful stimuli. One well-described phenomenon is LS lesion-induced "septal rage", an exaggerated defensive behavioral state (for review, see Sheehan et al., 2004). However, the LS also impacts food intake in multiple ways. First, the LS interacts with the viscera. Gastric distention excites or inhibits LS neurons, the appetitive gut hormone ghrelin excites LS neurons, and intra-LS ghrelin increases gastric clearance, allowing for consumption of more food (Gong et al., 2014). Second, the LS regulates neophagia, an avoidance of unfamiliar foods. LS histamine infusion reduces neophagia (Chee and Menard, 2013), as do LS lesions (Chee and Menard, 2011). Third, the LS controls food-directed motivation. LS electrical stimulation increases operant responding to obtain 
food (Altman and Wishart, 1971), while large LS lesions cause sporadic meal bout interruptions due to hyperactivity and diversion of efforts to grooming and exploration (Flynn et al., 1986). More recent work reveals that the ventral LS may be the locus for food-directed behavior. For instance, ventral LS lesions curb neophagia while dorsal LS lesions do not (Chee and Menard, 2011). Also, the inclusion of sucrose into a restricted feeding schedule diet induces c-fos expression in the ventral LS more robustly than in the dorsal LS (Mitra et al., 2011). These data implicate the LS in various aspects of feeding.

Particularly important is that the LS regulates food intake via opioid receptors. Injection of morphine or the delta receptor agonist (D-Ala $\left.{ }^{2}\right)$-Met-enkephalinamide (DALA) into the caudal LS increases in food intake in satiated rats, but LS administration of the broad spectrum opioid receptor agonist MR-2034 (Johnson and Pasternak, 1983) does not affect intake, as shown in Figure 2 (Stanley et al., 1988). Also, fasting promptly decreases leucine-enkephalin (Leu-Enk) fiber density in the LS (Kovács et al., 2005), where Leu-Enk is the endogenous ligand for mu and delta receptors. The authors propose that the decrease in apparent fiber density may be from increased release of Leu-Enk into the LS, implying that enkephalin input to the LS is a feeding signal. As fasting also increases NPY and galanin fiber density in the LS (Kovács et al., 2005, 2007), NPY and galanin input may shape this process. The LH is one potential source of LS enkephalin, galanin, and NPY input (Chronwall et al., 1985; Fallon and Leslie, 1986; Laque et al., 2013).

As mentioned before, the LS and the LH innervate each other (Deller et al., 1994; Risold and Swanson, 1997b; Duva et al., 2005). Fluorogold deposits in most LS subregions label neurons in the $\mathrm{LH}$, and $\mathrm{LH}$ Fluorogold infusions label many LS neurons. Further, both orexin and $\mathrm{MCH}$ fibers innervate the LS, and the LS expresses their receptors (Bittencourt et al., 1992; Marcus et al., 2001; Saito et al., 2001; Baldo et al., 2003). CART fibers also innervate the LS (Janzsó et al., 2010); some of these fibers likely originate from LH neurons co-expressing $\mathrm{MCH}$ (Broberger, 1999) or potentially from LepRb neurons co-transmitting GABA (Patterson et al., 2011; Laque et al., 2013). It is unclear whether orexin, $\mathrm{MCH}, \mathrm{CART}$, or GABA neurotransmission to the LS can directly affect food intake, though orexin can control food anticipatory behavior. Orexin neurons in the pfLH and lLH exhibit increased c-fos expression in animals anticipating a meal during a restricted feeding paradigm (Jiménez et al., 2013), and orexin expression in the LH is upregulated when this meal is a sweetened chow diet (Olszewski et al., 2009). Similarly, meal anticipation in food-restricted rats increases c-fos expression in the ventral LS, especially those given access to sucrose with their chow (Mitra et al., 2011). Thus, pfLH/lLH orexin neurons, operating potentially via the ventral LS, influence expectations of palatable meals when food availability is limited.

LS regions receiving $\mathrm{LH}$ innervation project to the AcbSh. The caudal LS, which is the primary LS recipient of LH input (Risold and Swanson, 1997b), sends terminals throughout the AcbSh with some LS neurons innervating the aAcbSh and many

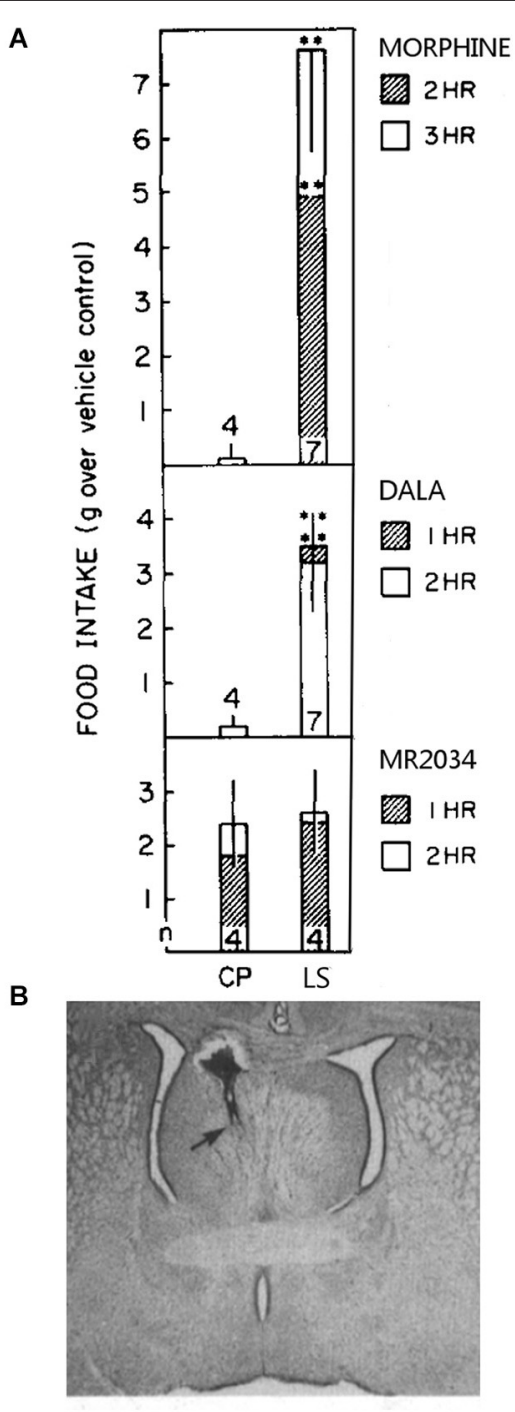

FIGURE 2 | Morphine and DALA increase food intake significantly above controls when injected into the caudal LS but not into the nearby caudate putamen (CP) (panel A). MR-2034 did not significantly increase intake in either of these brain areas. Numbers at the base of each bar represent the number of animals used per group. A Nissl-stained section with an injection site into the the border of the caudal LS and septofimbrial area is shown in panel (B). These figure components were adapted from a prior study (Stanley et al., 1988).

more innervating the pAcbSh (Brog et al., 1993). Particularly noteworthy is that the rostral LS projects to the aAcbSh (Zahm et al., 2013). As LS neurons are GABAergic (Zhao et al., 2013) and co-express either dynorphin or enkephalin (Fallon and Leslie, 1986; Harlan et al., 1987), caudal LS input to the whole AchSh is poised to retune food-directed behaviors, and rostral LS input specifically to the aAcbSh could potentiate hedonic valuation of tastes and food consumption (Reynolds and Berridge, 2002; Faure et al., 2010; Castro and Berridge, 2014a). Further, the LS can generally inform the AcbSh of predicted availability of regular and palatable meals. By interacting with the LS, the LH can control various aspects of AcbSh-mediated feeding. 


\section{THE VENTRAL PALLIDUM}

The VP, a basal forebrain region, has recently become an area of much interest in the research fields of drug abuse and food intake. This region shares some of the properties of its more rostral neighbor, the accumbens, in that it also possesses medium spiny neurons (Kupchik and Kalivas, 2013). However, more caudal and lateral areas of the VP have medium-sized aspiny GABAergic neurons that fire spontaneously. Further, although the VP has cholinergic neurons like those in the accumbens, VP cholinergic neurons project to other brain areas instead of serving solely as interneurons (Carlsen et al., 1985). The entirety of the VP is anatomically identified by a dense Substance P-immunoreactive fiber network, and is subdivided by strong neurotensin and strong calbindin staining in the anteromedial and posterolateral parts of the VP, respectively (Zahm, 1989; Zahm et al., 1996). As the VP diagonally traverses the basal forebrain from rostromedial to caudolateral (Paxinos and Watson, 2013), we henceforth refer to $\mathrm{VP}$ subdivisions as anteromedial ( $\mathrm{amVP})$ or posterolateral (plVP).

The VP is implicated in the "liking" of foods and the motivation to feed (for detailed review, see Castro and Berridge, 2014b). VP neurons are excited by sucrose reward and cues that predict it (Tindell et al., 2004). VP neurons also increase firing when sucrose solutions are infused into the mouth (Tindell et al., 2006). Interestingly, salt solutions that are aversive to sodium-replete rats do not increase VP neuron firing, but such solutions robustly increase VP neuron firing in sodiumdepleted rats (Tindell et al., 2006). This effect highlights the VP's role in the hedonic evaluation of tastes and how it can be altered by homeostatic signals. Lesions of the VP, and not surrounding structures such as the $\mathrm{LH}$, produce aversion to otherwise pleasurable tastants (Cromwell and Berridge, 1993); such effects are mediated primarily through the plVP (Ho and Berridge, 2014). VP lesions also disrupt the acquisition of foodassociated conditioned place preference (McAlonan et al., 1993), indicating a role for the VP in learning about food-associated cues.

Numerous neuropharmacological studies have described behavioral roles of specific neurotransmitter receptors within the VP. VP $\mathrm{GABA}_{\mathrm{A}}$ receptor activation decreases intake and increases negative orofacial responses to palatable, neutral, and unpalatable solutions (Shimura et al., 2006). Interestingly, this inhibition of the plVP decreases effort to procure palatable food, yet increases chow intake in rats given the choice between sucrose and chow (Farrar et al., 2008). Conversely, VP GABA $\mathrm{A}$ receptor blockade increases food intake (Stratford et al., 1999) and causes a robust preference for foods high in fat (Covelo et al., 2014). VP orexin receptor or MOR activation increases "liking" reactions to sweet foods (Smith and Berridge, 2005; Ho and Berridge, 2013). The fact that VP MOR activation increases "liking" reactions may seem paradoxical, given that opioids inhibit VP neurons (Mitrovic and Napier, 1995). However, opioid input can disinhibit VP neurons via inhibition of inhibitory presynaptic inputs (Napier et al., 1992; Kupchik et al., 2014). Collectively, these manipulations indicate that certain neurotransmitters act within the VP to regulate the motivation to procure and the liking of foods, as well as altering macronutrient selection.
Anatomical work links the LH, VP, and AcbSh. LH projections innervate the VP and surrounding basal forebrain areas (Cullinan and Záborszky, 1991; Goto et al., 2005; Hahn and Swanson, 2010). These projections arise from the pfLH and $\mathrm{LLH}$, particularly from orexin neurons (Baldo et al., 2003) and potentially from LepRb neurons (Patterson et al., 2011). Some projections also originate from the vlLH (Cullinan and Záborszky, 1991). The VP in turn projects to the accumbens in a topographic manner (Haber et al., 1985). The amVP projects to the anterior half of AcbSh, the subcommissural VP projects to the AcbC, and the plVP projects to the lateral pAcbSh (Phillipson and Griffiths, 1985; Brog et al., 1993). Most of these VP to AcbSh projections utilize GABA as their neurotransmitter, as suggested by stains for GAD mRNA (Churchill and Kalivas, 1994). These VP neurons may also use opioid peptides as co-transmitters (Fallon and Leslie, 1986; Harlan et al., 1987).

Functional evidence also links these three brain regions. VP electrical stimulation induces c-fos expression in the accumbens, including the aAcbSh (Panagis et al., 1997). MOR activation in the plVP induces increased c-fos expression in the pAcbSh, while MOR antagonism reduces baseline c-fos expression in both aAcbSh and pAcbSh. Further, MOR antagonism in the aAcbSh blunts plVP MOR-mediated food intake and plVP MORelicited increases in "liking" of foods (Smith and Berridge, 2007), indicating a VP to AcbSh opioid projection. Paradoxically, though these hedonic "hotspots" functionally interact, they do not directly innervate each other; the amVP "coldspot" innervates the aAcbSh "hotspot" and the plVP "hotspot" innervates the lateral pAcbSh (Phillipson and Griffiths, 1985; Brog et al., 1993). Further investigation of intra-accumbal and intra-pallidal processing may resolve this issue. Additionally, as VP disinhibition induces a preference for fatty foods, it would be interesting to see if VP to AcbSh signaling is involved with fatty food preferences induced by accumbens MOR activation (Zhang et al., 1998).

Anatomical evidence suggests that the LH secretes orexin, opioids, and GABA (from LepRb neurons) into the VP (Fallon and Leslie, 1986; Baldo et al., 2003; Patterson et al., 2011; Laque et al., 2013). The VP then sends GABAergic and opioidergic input to the AcbSh (Fallon and Leslie, 1986; Harlan et al., 1987; Churchill and Kalivas, 1994). Indeed, accumbens-projecting VP neurons likely receive input from the pfLH and vlLH (Figure 3). How then may this LH-VP-AcbSh circuit influence feeding? Activation of the LH LepRb neuron population or another GABAergic population can inhibit the VP and suppress intake either by causing foods to become "disliked" or by hindering motivation to obtain foods. In particular, if the LH secretes GABA to the amVP, this would in turn release the aAcbSh from VP inhibition and also suppress feeding. Conversely, orexin or enkephalin input from the LH to the plVP could increase hedonic perception of foods, and can further enhance this effect via activation of the aAcbSh (Smith and Berridge, 2007). Thus, the LH sends homeostatic signals to the VP, which alter the hedonic evaluation of foods and the motivation to procure them. This information is then sent to the AcbSh to transform these motivational and hedonic signals into the initiation or cessation of food procurement and consumption. 

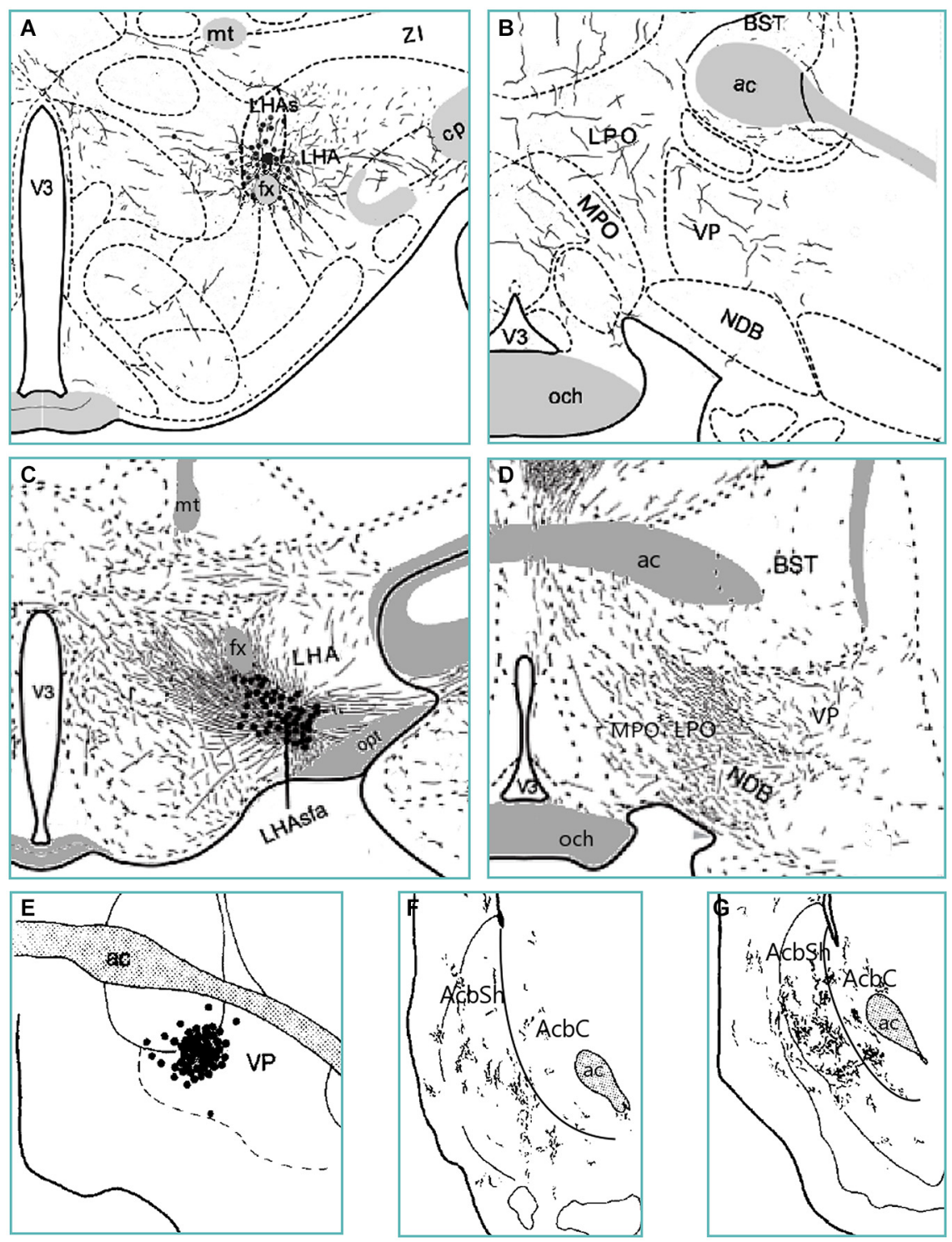

FIGURE 3 | Anterograde tract tracing evidence from various studies indicates an ascending trans-pallidal $\mathrm{LH}$ to AcbSh circuit in the rat brain. PHA-L-infiltrated neurons in the suprafornical LH (LHAs; panel $\mathbf{A}$ ) and the anterior subfornical LH (LHAsfa; panel C) send moderate amounts of fibers to the amVP (panels B and D) (Goto et al., 2005; Hahn and Swanson, 2010). PHA-L-labeled neurons in the amVP (panel E) send projections to the anterior (panel F) and especially posterior (panel G) medial AcbSh (Groenewegen et al., 1993). Thus, the VP subregion receiving LH input projects in turn to the medial AcbSh. Abbreviations: BST—bed nucleus of the stria terminalis; $\mathrm{cp}$ —cerebral peduncle; $\mathrm{fx}$-fornix; LHA—lateral hypothalamic area; LPO_lateral preoptic area; MPO_-medial preoptic area; mt-mammillothalamic tract; NDB—diagonal band nucleus; och—optic chiasm; opt—optic tract; V3—-third ventricle; VP—ventral pallidum; ZI—zona incerta.

\section{THE PARAVENTRICULAR THALAMIC NUCLEUS}

In the rat, the PVT is the most dorsomedial region of the midline thalamus (Paxinos and Watson, 2013). This brain region is comprised of small aspiny neurons. Though behavioral studies discriminate between anterior (aPVT) and posterior (pPVT) subregions, cellular morphology does not clearly reflect this division (Kolaj et al., 2014). PVT neurons are predominantly glutamatergic (Hur and Zaborszky, 2005).

Activation studies examining c-fos expression demonstrate how the PVT, particularly its anterior part, is activated by multiple food-associated and metabolic signals. The PVT tracks the time of day; c-fos expression changes within the aPVT and pPVT based on time of day (Novak and Nunez, 1998). Of particular note is that, in restricted feeding schedules, aPVT c-fos expression increases prior to expected meal availability, and these increases correlate with food anticipatory indicators such as increased locomotion and increased blood corticosterone. These data suggest that the aPVT is a time-keeping oscillator and regulates food anticipatory behaviors in situations of intermittent food access (Nakahara et al., 2004). Further, aPVT 
activity is also modulated by meal palatability in both restricted and non-restricted paradigms. In restricted feeding schedules, addition of a palatable meal increases food anticipationassociated c-fos expression in the aPVT (Mendoza et al., 2005; Mitra et al., 2011). In ad libitum fed rats, aPVT c-fos expression increases in contexts that signal availability of a saccharin solution (Igelstrom et al., 2010), and aPVT orexinreceptor containing neurons increase c-fos expression in contexts associated with chocolate delivery (Choi et al., 2010). The aPVT also receives metabolic signals; systemic insulin administration and insulin-mediated lard intake increase c-fos within the aPVT but not the pPVT (Warne et al., 2007). These studies show how the aPVT is activated by information about meal timing, availability of palatable foods, and peripheral signals of satiety.

Lesion studies further associate the PVT with food anticipation, food intake, and metabolism. Lesions of the aPVT reduce food anticipatory-mediated increases in blood corticosterone and locomotion without affecting food intake (Nakahara et al., 2004) whereas pPVT lesions increase food intake and body weight, and chronic stress causes this weight gain to shift toward subcutaenous white adipose tissue (Bhatnagar and Dallman, 1999). It should be noted that the pPVT regulates habituation to chronic stressors, as pPVT lesions attenuate this habituation (Bhatnagar et al., 2002). Thus, the aPVT governs food anticipatory signaling and the pPVT regulates food intake, body weight, stress-induced changes in metabolism, and likely stress-mediated eating.

Neuropharmacological evidence examining PVT orexin and GABA input also implicates the PVT in food intake regulation. Orexin 1 receptor knockdown in the pPVT decreases high fat diet consumption without affecting progressive ratio breakpoint for high fat foods in either satiated or food-deprived conditions (Choi et al., 2012). Also, orexin A infusion into the pPVT, but not the aPVT, increases sucrose intake (Barson et al., 2014), and pPVT orexin 1 receptor knockdown decreases high fat chow intake (Choi et al., 2012). As orexin excites pPVT neurons (Ishibashi et al., 2005; Heydendael et al., 2011), it is paradoxical then that pPVT muscimol injection also increases food intake (Stratford and Wirtshafter, 2013). Orexin and GABA may act on different pPVT neuron populations to produce similar food intake effects.

The LH innervates the PVT, as confirmed by anterograde (Goto et al., 2005; Hahn and Swanson, 2010) and retrograde (Chen and Su, 1990; Kirouac et al., 2006; Li and Kirouac, 2012) tracing studies. This hypothalamic projection consists of orexin and its co-transmitter glutamate, verified by PVT orexin receptor expression (Marcus et al., 2001) and orexin fibers within the PVT (Baldo et al., 2003; Parsons et al., 2006). CART fibers also innervate the PVT (Kampe et al., 2009), and such innervation originates partly from the pfLH and vlLH (Kirouac et al., 2006). Although MCH colocalizes with CART in some LH neurons (Broberger, 1999) and the PVT possesses MCH receptors (Saito et al., 2001), few MCH-containing fibers terminate in the PVT (Lee et al., 2014), suggesting that LH to PVT CART innervation does not use $\mathrm{MCH}$ as a co-transmitter. Instead, LH LepRb neurons (Patterson et al., 2011; Laque et al., 2013) may secrete CART to the PVT. The PVT also expresses receptors for endogenous opioids and CRF, and the PVT receives CRF input from the pfLH (Minami et al., 1993; George et al., 1994; Potter et al., 1994; Otake and Nakamura, 1995; Ding et al., 1996). Interestingly, LH orexin and CART inputs innervate AcbSh-projecting PVT neurons throughout the PVT's rostrocaudal axis (Parsons et al., 2006). The concept that the PVT receives hypothalamic CART and orexin signals and sends this information onward to the AcbSh has been proposed previously (Kelley et al., 2005b; Martin-Fardon and Boutrel, 2012). There is also a vlLH projection to the PVT (Chen and Su, 1990) that uses GABA and possibly glutamate (Vong et al., 2011).

In turn, the PVT projects to the AcbSh (Brog et al., 1993; Moga et al., 1995; Parsons et al., 2006; Li and Kirouac, 2008; Vertes and Hoover, 2008; Hsu and Price, 2009). Though initially some evidence indicated that glutamatergic PVT to AcbSh projections innervate cholinergic interneurons (Meredith and Wouterlood, 1990), more recent evidence showed that these PVT to AcbSh projections instead innervate AcbSh medium spiny neurons (Ligorio et al., 2009), though these inputs may still act on cholinergic interneurons via extrasynaptic mechanisms. Both the aPVT and pPVT project to the aAcbSh and pAcbSh (Li and Kirouac, 2008), allowing both PVT regions to influence feeding behavior through both AcbSh subregions. Considering that the PVT secretes glutamate to the AcbSh (Ligorio et al., 2009), inhibition of the PVT presumably halts this glutamatergic input. AcbSh AMPA receptor blockade increases the motivation to eat (Maldonado-Irizarry et al., 1995; Reynolds and Berridge, 2003); this manipulation mimics cessation of AcbSh glutamate input. Further, in non-stressful environments, decreased glutamate release to both the aAcbSh and most of the pAcbSh can induce appetitive behaviors (Reynolds and Berridge, 2008). Thus, PVT inhibition would suppress glutamate release to the AcbSh, allowing for the initiation of food intake.

Although it is likely that multiple glutamatergic inputs, not solely the PVT, regulate AcbSh-mediated feeding, the PVT likely has at least a modulatory role on food intake. Electrophysiological data indicates that although PVT input to the AcbSh produces EPSPs, it does not produce action potentials as other glutamatergic inputs do (O'Donnell and Grace, 1995). However, it remains unclear whether a specific afferent source, or a collection of sources, controls AcbSh glutamate-mediated feeding. Synaptic glutamate levels in the AcbSh decrease during the onset of feeding (Rada et al., 1997), indicating that multiple glutamatergic AcbSh afferents must suppress their input to allow for feeding to occur. Also, inhibition of prefrontal cortical inputs alone does not increase food intake; suppression of additional glutamate inputs is required to initiate feeding (Richard and Berridge, 2013). The PVT may be an additional input whose activity must also decrease in order to decrease AcbSh synaptic glutamate and allow for the initiation of food intake.

The concept of an LH to PVT to AcbSh circuit is supported by the effects of GABA in the PVT and glutamate effects in the AcbSh. Activating pPVT $\mathrm{GABA}_{\mathrm{A}}$ receptors induces eating (Stratford and Wirtshafter, 2013). Inhibitory input from the LH 
to the pPVT, via pfLH/lLH CART neurons and their GABA cotransmission, from pfLH opioid-secreting neurons (Brunton and Charpak, 1998), from LH CRF neurons (Siggins et al., 1985), or from vlLH GABA neurons, would halt pPVT excitatory input to the aAcbSh and pAcbSh. By this circuit, inhibitory LH inputs to the pPVT decrease glutamate release in the AcbSh, allowing for feeding to occur.

However, excitation of pPVT neurons, via orexin receptor activation, also induces intake (Barson et al., 2014; Kolaj et al., 2014). How might increased PVT glutamate output to the AcbSh increase food-directed behavior? One explanation may lie in different PVT neuron populations-those mediating GABAelicited feeding and those mediating orexin-elicited feedinginnervating different postsynaptic targets in the AcbSh. More specifically, PVT neurons regulating GABA-elicited feeding may project to AcbSh projection neurons, whereas PVT neurons regulating orexin-elicited feeding may project to AcbSh GABAergic interneurons. Such differences in PVT neuron projection patterns need to be verified, however.

An alternate explanation is the existence of a presynaptic "brake" on glutamatergic inputs to the AcbSh. Most AcbSh glutamatergic afferents, including the PVT, express the inhibitory mGluR2 presynaptically (Conn and Pin, 1997; Gu et al., 2008), and activation of mGluR2 within the AcbSh decreases glutamate release, an effect that persists for several minutes due to formation of presynaptic long term depression (Kahn et al., 2001; Xi et al., 2002). Robust PVT glutamate release within the AcbSh would then activate PVT mGluR2 autoreceptors or mGluR2 heteroreceptors (on other glutamatergic terminals), suppressing further glutamate release into the AcbSh. PVT-mediated excess glutamate release into the AcbSh that would trip this "brake" can occur from: (1) strong excitation of the pPVT by orexin and glutamate input from the LH (Kolaj et al., 2014), (2) excitation of the pPVT by activation of the aPVT from palatable food contexts and/or metabolic signals (Vertes and Hoover, 2008); and (3) excitation of the prefrontal cortex by PVT neurons that collateralize to both the AcbSh and the prefrontal cortex (Bubser and Deutch, 1998; Otake and Nakamura, 1998). It should be noted that AcbSh neurons have two resting membrane potentials - a slightly depolarized "up" state and a hyperpolarized "down" state (O’Donnell and Grace, 1995; O'Donnell et al., 1999). Although excess glutamate input would elicit action potentials in AcbSh neurons in their "up" state (Lape and Dani, 2004), simultaneous GABAergic inputs from other sources would maintain AcbSh neurons in their "down" state. In situations where GABAergic inputs to the AcbSh drive neurons to their "down" state, excess extracellular glutamate may not induce action potentials and instead may inhibit further presynaptic glutamate release. As a result, inhibitory inputs to AcbSh neurons maintain these neurons in their "down" state and permit the initiation of feeding unhindered by glutamate input. This "presynaptic brake" hypothesis requires substantial verification, however. In particular, it is unclear whether robust PVT glutamate release into the AcbSh shuts down AcbSh glutamate inputs in this manner, and it must be determined whether such a mode of input deactivation specifically induces food-oriented behaviors.
In summary, LH input informs PVT subregions of bodily nutrient states and palatable food availability. Then, this input modulates aPVT-mediated palatable food anticipation and metabolic signaling as well as modifying the pPVT's motivational signals to procure foods. Finally, these PVT divisions can collectively potentiate food-directed behaviors through the aAcbSh and pAcbSh, particularly in non-stressful familiar environments. Further anatomical study can clarify whether specific PVT neuron subsets, such as those governing GABAmediated food intake vs. others governing orexin-mediated intake, selectively innervate AcbSh projection neurons or AcbSh interneurons.

\section{CONCLUSIONS}

Here we have described multiple ways that the $\mathrm{LH}$ can regulate food intake via the AcbSh both directly and indirectly, and can do so by altering various aspects of food-seeking behavior. Multiple subdivisions of the LH differentially innervate the AcbSh and utilize different combinations of neurotransmitters. Neurotransmitters localized in the LH are implicated in food intake and effort to procure foods, and administration of LHoriginating neuropeptides or their antagonists into the AcbSh impact such behaviors. Also, the $\mathrm{LH}$ projects to numerous other brain regions, some of which project to the AcbSh, regulate its activity, and subsequently influence food-directed behaviors. A collection of the pathways we have described can be found in Table 1. We highlight a subcortical network that serves to regulate aspects of food procurement and consumption.

The AcbSh and the LH have a direct bidirectional anatomical connection (Usuda et al., 1998; Kampe et al., 2009). This bidirectional circuit serves to increase feeding in both directions of its signaling. For example, inhibition of the AcbSh disinhibits the LH (Stratford, 2005), in particular orexin neurons (Baldo et al., 2004), and can drive food intake through this descending pathway. On the other hand, the feeding induced by excitation of the LH via glutamate receptor agonists (Stanley et al., 1993a) may act in part by activating orexin, $\mathrm{MCH}$, or other LH neurons (Obukuro et al., 2010; Li et al., 2011) and by increasing their peptidergic output to the AcbSh. Indeed, intraAcbSh orexin induces feeding while orexin antagonists suppress feeding (Thorpe and Kotz, 2005). Alternatively, anorectic peptides secreted from the LH to the AcbSh such as CART may antagonize the descending AcbSh- $\mathrm{LH}$ pathway, as may LH GABA neurotransmission to the pAcbSh. Also, the anterior vlLH receives input specifically from the aAcbSh hedonic hotspot (Thompson and Swanson, 2010), the vlLH region shows increased c-fos expression after aAcbSh inhibition (Baldo et al., 2004), and the vlLH projects back to the pAcbSh with GABA (Vong et al., 2011). This LH feedback may serve to re-tune the hedonic perception of foods. Energy state signals modulate LH activity and reduce feeding by blunting appetite-inducing signals transmitted to the AcbSh, which then inform the LH to avoid or cease intake.

Here we have also proposed or added to three potential indirect pathways by which the $\mathrm{LH}$ can regulate AcbSh activity, either by modulating the motivation to feed or by changing the 
Table 1 | Anatomical evidence for direct projections and their neurotransmitters.

\begin{tabular}{|c|c|c|c|}
\hline Projection & Origin of evidence & $\begin{array}{l}\text { Neurotransmitters } \\
\text { used }\end{array}$ & Origin of evidence \\
\hline $\begin{array}{l}\mathrm{pfLH} \rightarrow \text { AcbSh, } \\
\mathrm{ILH} \rightarrow \text { AcbSh }\end{array}$ & $\begin{array}{l}\text { Phillipson and Griffiths (1985), Brog } \\
\text { et al. (1993), Kampe et al. (2009), } \\
\text { Hahn and Swanson (2010) }\end{array}$ & Orexin, $\mathrm{MCH}^{*}$ & $\begin{array}{l}\text { Bittencourt et al. (1992), Trivedi } \\
\text { et al. (1998), Saito et al. (2001), } \\
\text { Baldo et al. (2003), Kampe et al. } \\
\text { (2009) }\end{array}$ \\
\hline $\mathrm{vlLH} \rightarrow \mathrm{pAcbSh}$ & $\begin{array}{l}\text { Phillipson and Griffiths (1985), Brog } \\
\text { et al. (1993), Goto et al. (2005) }\end{array}$ & GABA & Vong et al. (2011) \\
\hline $\mathrm{VILH} \rightarrow \mathrm{LS}$ & Risold and Swanson (1997b) & GABA & Vong et al. (2011) \\
\hline $\mathrm{LS} \rightarrow$ AcbSh & $\begin{array}{l}\text { Brog et al. (1993), Zahm et al. } \\
\text { (2013) }\end{array}$ & GABA & Zhao et al. (2013) \\
\hline $\mathrm{VILH} \rightarrow \mathrm{PVT}$ & Chen and Su (1990) & GABA & Vong et al. (2011) \\
\hline $\mathrm{PVT} \rightarrow \mathrm{AcbSh}$ & $\begin{array}{l}\text { Meredith and Wouterlood (1990), } \\
\text { Brog et al. (1993), Parsons et al. } \\
\text { (2006), Vertes and Hoover (2008), } \\
\text { Ligorio et al. (2009) }\end{array}$ & Glutamate & $\begin{array}{l}\text { Meredith and Wouterlood (1990), } \\
\text { Ligorio et al. (2009) }\end{array}$ \\
\hline $\begin{array}{l}\mathrm{pfLH} \rightarrow \mathrm{VP} \\
\mathrm{ILH} \rightarrow \mathrm{VP}\end{array}$ & $\begin{array}{l}\text { Cullinan and Záborszky (1991), } \\
\text { Hahn and Swanson (2010) }\end{array}$ & Orexin* & Baldo et al. (2003) \\
\hline $\mathrm{VlLH} \rightarrow \mathrm{VP}$ & Goto et al. (2005) & GABA & Vong et al. (2011) \\
\hline $\mathrm{VP} \rightarrow$ AcbSh & $\begin{array}{l}\text { Haber et al. (1985), Phillipson and } \\
\text { Griffiths (1985), Brog et al. (1993) }\end{array}$ & GABA & Churchill and Kalivas (1994) \\
\hline
\end{tabular}

${ }^{*}$ Certain co-transmitters are assumed for specific neuron types. Specifically, orexin is co-transmitted with glutamate and dynorphin, MCH with GABA, and CART with GABA.

reward value of foods. These routes are summarized in Figure 4 and in the following statements.

1. The LH sends projections to the LS (Deller et al., 1994) which contain orexin, MCH, CART, GABA, and potentially other neurotransmitters (Bittencourt et al., 1992; Broberger, 1999; Baldo et al., 2003; Janzsó et al., 2010). Also, opioids that originate from the LH (Fallon and Leslie, 1986) could directly mediate feeding behavior via the caudal LS (Stanley et al., 1988), a region that receives much LH input (Risold and Swanson, 1997b). As such, the LH is arranged to alter LS-mediated food-anticipatory rhythms and foodseeking behavior with homeostatic information (such as food deprivation or sudden availability of palatable food), and can use LS GABAergic and opioidergic outputs to induce feeding via the AcbSh.

2. The plVP receives orexin input from the $L H$ that enhances liking of foods (Ho and Berridge, 2013). VP GABA input and plVP opioid input can directly affect food intake (Smith and Berridge, 2005; Shimura et al., 2006), and such input arises in part from the LH (Fallon and Leslie, 1986; Chou et al., 2001). The VP in turn is poised to inhibit the AcbSh through GABAergic or opioidergic input (Harlan et al., 1987; Churchill and Kalivas, 1994) and may drive food intake via this input. Thus, palatable food availability or homeostatic state signals processed by the $\mathrm{LH}$ can influence the hedonic valuation of foods, food-directed effort, and fat preference governed by the VP. This LH to VP input subsequently modulates VP GABAergic and opioid input to the AcbSh and re-tunes foodassociated affective and motivated behaviors.

3. LH input can excite the aPVT and pPVT through orexin innervation (Ishibashi et al., 2005), or inhibit these areas via CART, enkephalin, GABA, or CRF (Kolaj et al., 2014). Activation of pPVT orexin and $\mathrm{GABA}_{\mathrm{A}}$ receptors induces food intake (Stratford and Wirtshafter, 2013; Barson et al., 2014), suggesting that LH neuron groups differentially regulate feeding via the pPVT. Both the aPVT and pPVT in turn send glutamatergic projections to the AcbSh, which, when halted, allows for feeding to occur via both the aAcbSh and pAcbSh in non-stressful situations (Reynolds and Berridge, 2008). Inhibitory input from the LH to the pPVT would suppress glutamate input to the AcbSh. Alternatively, orexin neurons that fire to palatable food cues excite aPVT neurons, which then activate pPVT neurons via intra-PVT glutamatergic innervation, and orexin innervation of the pPVT further enhances this excitation. Excess glutamate release from the pPVT to the AcbSh activates presynaptic autoreceptors or heteroreceptors, which then halt AcbSh glutamate input and induce motivation to feed. By this route, the LH alters PVT activity and subsequently changes food anticipation, 


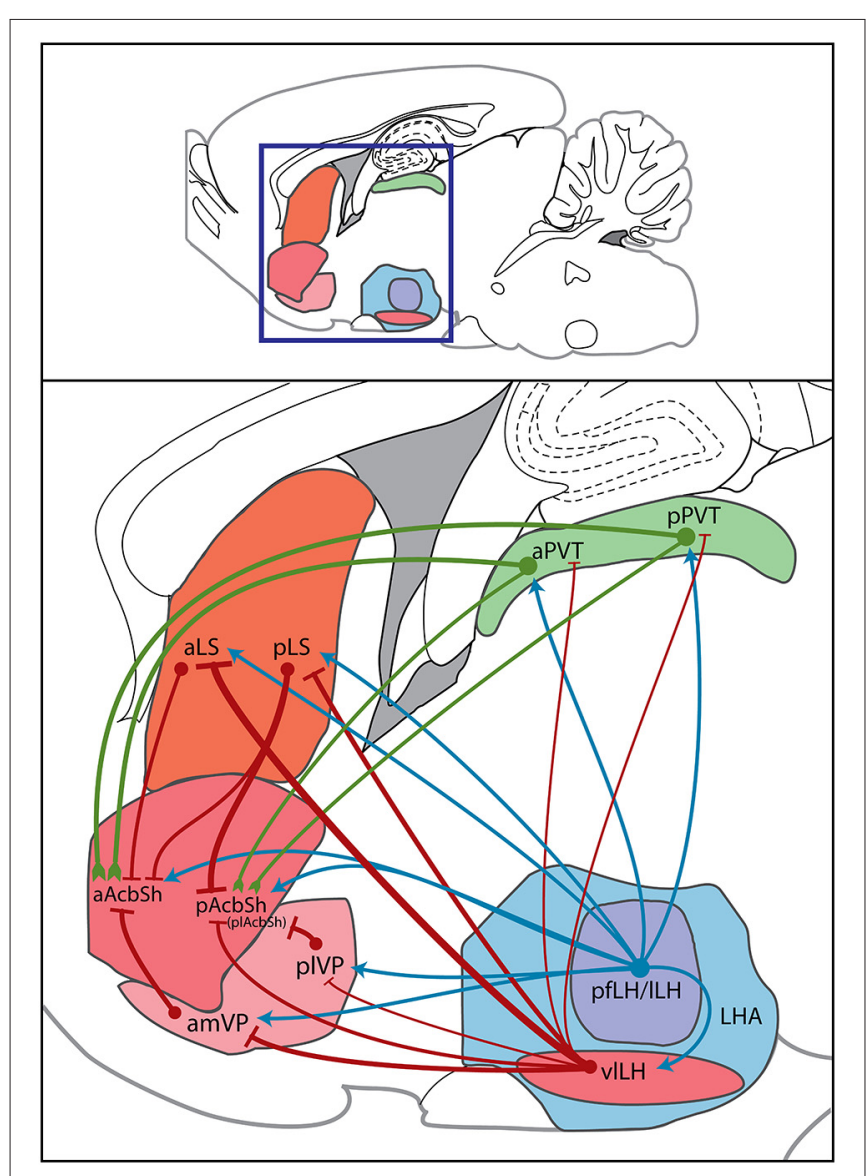

FIGURE 4 | Sagittal diagram of direct hypothalamic and indirect trans-pallidal, trans-thalamic, and trans-septal innervation of the AcbSh. Within a sagittal plane, the boxed region designates an area of the rat forebrain within which the regions of interest reside (top panel); this area is magnified to show sources of AcbSh innervation (bottom panel). Subregions of the LH area (LHA), the pfLH, ILH, and vlLH, project both directly to the AcbSh and to other regions that project onward to the AcbSh. Green lines indicate glutamatergic signals, red lines indicate GABAergic signals, and blue lines indicate mixed or neuropeptidergic signals. Circles indicate cell bodies. Line thickness denotes "strength" of connections. Such strengths were determined by amounts of anterogradely labeled fibers or retrogradely labeled cells observed in prior studies of each specific projection. This sagittal template was modified from a brain atlas (Paxinos and Watson, 2013). plAcbSh-posterolateral AcbSh.

food procurement, and food selection, and this alteration of PVT activity modulates food intake through changes in PVT glutamatergic input to the AcbSh.

A few issues arise when interpretting the wealth of aforementioned anatomical data. One issue is that many tracing studies do not specify whether LH projections innervate LS/VP/PVT projection neurons or interneurons. Also, inputs to these brain regions could be en passant, allowing the LH to regulate not only these but other regions receiving collaterals. Further, some anatomical studies using light microscopy rely on visualizing varicosities to suggest innervation of an efferent target, though such innervation may not actually occur in the observed brain region. Visualization of these circuits with electron microscopy can resolve these issues, and further investigation with other methods can properly define the purpose of specific projections in these described circuits. Such data will paint a more complete picture of how energy state integrators impact the motivation to feed and the rewarding value of foods.

Considering the various avenues by which homeostatic and sensory inputs can inform AcbSh-mediated motivational and reward-related processing, how then is such processing executed into action? We have mentioned that AcbSh output is routed back through the $\mathrm{LH}$ in order to initiate feeding. Indeed, the $\mathrm{LH}$ is required for AcbSh-mediated feeding behavior (Stratford and Wirtshafter, 2012b). However, as the AcbSh translates motivation into the initiation of movement patterns, it does so through multiple efferent targets aside from the LH. Such downstream regions include the globus pallidus, VP, and mesencephalic motor regions, all of which regulate aspects of AcbSh-mediated goal-directed actions (Jones and Mogenson, 1980; Brudzynski et al., 1993; Stratford and Wirtshafter, 2012b). It is via these multiple downstream regions that the AcbSh initiates the seeking of goals such as foods, yet the LH is an essential component of this food intake-controlling network in that its ablation (Stratford and Wirtshafter, 2012b) or its inhibition (Urstadt et al., 2013a) halts AcbSh-mediated feeding and not other behaviors.

Drawing conclusions about brain structure functions from lesion and microinjection studies can be difficult if careful scrutiny is not paid to the specific anatomical spaces involved. Overlaying "empirical” functional spaces with native chemoarchitecture and connectivity maps in future studies is absolutely essential for delineating the exact neural substrates by which certain aspects of a behavior, such as food intake, are regulated (Khan, 2013). Towards this goal, we present and add to a subcortical framework formed from functional studies, activation maps, and connectivity patterns showing how the LH interacts directly and indirectly with the AcbSh. Through this arrangement of connections, the LH can directly and indirectly alter food-oriented behaviors governed by the AcbSh. In turn, the AcbSh sends signals to motor effectors and the LH to initiate the vital behavior of feeding.

\section{REFERENCES}

Altman, J. L., and Wishart, T. B. (1971). Motivated feeding behavior elicited by electrical stimulation of the septum. Physiol. Behav. 6, 105-109. doi: 10. 1016/0031-9384(71)90076-x

Apicella, P., Ljungberg, T., Scarnati, E., and Schultz, W. (1991b). Responses to reward in monkey dorsal and ventral striatum. Exp. Brain Res. 85, 491-500. doi: $10.1007 /$ bf00231732

Apicella, P., Scarnati, E., and Schultz, W. (1991a). Tonically discharging neurons of monkey striatum respond to preparatory and rewarding stimuli. Exp. Brain Res. 84, 672-675. doi: 10.1007/bf00230981

Baldo, B. A., Daniel, R. A., Berridge, C. W., and Kelley, A. E. (2003). Overlapping distributions of orexin/hypocretin- and dopamine-beta-hydroxylase immunoreactive fibers in rat brain regions mediating arousal, motivation and stress. J. Comp. Neurol. 464, 220-237. doi: 10.1002/cne.10783

Baldo, B. A., Gual-Bonilla, L., Sijapati, K., Daniel, R. A., Landry, C. F., and Kelley, A. E. (2004). Activation of a subpopulation of orexin/hypocretincontaining hypothalamic neurons by GABAA receptor-mediated inhibition of the nucleus accumbens shell, but not by exposure to a novel environment. Eur. J. Neurosci. 19, 376-386. doi: 10.1111/j.1460-9568.2004. 03093.x 
Barson, J. R., Ho, H. T., and Leibowitz, S. F. (2014). Anterior thalamic paraventricular nucleus is involved in intermittent access ethanol drinking: role of orexin receptor 2. Addict. Biol. doi: 10.1111/adb.12139. [Epub ahead of print].

Berridge, K. C. (1991). Modulation of taste affect by hunger, caloric satiety and sensory-specific satiety in the rat. Appetite 16, 103-120. doi: 10.1016/01956663(91)90036-r

Bhatnagar, S., and Dallman, M. F. (1999). The paraventricular nucleus of the thalamus alters rhythms in core temperature and energy balance in a statedependent manner. Brain Res. 851, 66-75. doi: 10.1016/s0006-8993(99)02108-3

Bhatnagar, S., Huber, R., Nowak, N., and Trotter, P. (2002). Lesions of the posterior paraventricular thalamus block habituation of hypothalamic-pituitary-adrenal responses to repeated restraint. J. Neuroendocrinol. 14, 403-410. doi: 10.1046/j. 0007-1331.2002.00792.x

Bittencourt, J. C., Presse, F., Arias, C., Peto, C., Vaughan, J., Nahon, J.-L., et al. (1992). The melanin-concentrating hormone system of the rat brain: an immuno- and hybridization histochemical characterization. J. Comp. Neurol. 319, 218-245. doi: 10.1002/cne.903190204

Broberger, C. (1999). Hypothalamic cocaine- and amphetamine-regulated transcript (CART) neurons: histochemical relationship to thyrotropinreleasing hormone, melanin-concentrating hormone, orexin/hypocretin and neuropeptide Y. Brain Res. 848, 101-113. doi: 10.1016/s0006-8993(99) 01977-0

Broekkamp, C. L., Pijnenburg, A. J., Cools, A. R., and Van Rossum, J. M. (1975). The effect of microinjections of amphetamine into the neostriatum and the nucleus accumbens on self-stimulation behaviour. Psychopharmacologia 42, 179-183. doi: 10.1007/bf00429550

Brog, J. S., Salyapongse, A., Deutch, A. Y., and Zahm, D. S. (1993). The patterns of afferent innervation of the core and shell in the "accumbens" part of the rat ventral striatum: immunohistochemical detection of retrogradely transported fluoro-gold. J. Comp. Neurol. 338, 255-278. doi: 10.1002/cne.903380209

Brudzynski, S. M., Wu, M., and Mogenson, G. J. (1993). Decreases in rat locomotor activity as a result of changes in synaptic transmission to neurons within the mesencephalic locomotor region. Can. J. Physiol. Pharmacol. 71, 394-406. doi: 10.1139/y93-060

Brunton, J., and Charpak, S. (1998). $\mu$-opioid peptides inhibit thalamic neurons. J. Neurosci. 18, 1671-1678.

Bubser, M., and Deutch, A. Y. (1998). Thalamic paraventricular nucleus neurons collateralize to innervate the prefrontal cortex and nucleus accumbens. Brain Res. 787, 304-310. doi: 10.1016/s0006-8993(97)01373-5

Burdakov, D., and González, J. A. (2009). Physiological functions of glucoseinhibited neurones. Acta Physiol. (Oxf). 195, 71-78. doi: 10.1111/j.1748-1716. 2008.01922.x

Carlsen, J., Záborszky, L., and Heimer, L. (1985). Cholinergic projections from the basal forebrain to the basolateral amygdaloid complex: a combined retrograde fluorescent and immunohistochemical study. J. Comp. Neurol. 234, 155-167. doi: 10.1002/cne.902340203

Castro, D. C., and Berridge, K. C. (2014a). Opioid hedonic hotspot in nucleus accumbens shell: mu, delta and kappa maps for enhancement of sweetness "liking" and "wanting". J. Neurosci. 34, 4239-4250. doi: 10.1523/JNEUROSCI. 4458-13.2014

Castro, D. C., and Berridge, K. C. (2014b). Advances in the neurobiological bases for food "liking" versus "wanting". Physiol. Behav. 136, 22-30. doi: 10.1016/j. physbeh.2014.05.022

Charles, J. R., Duva, M. A., Ramirez, G. J., Lara, R. L., Yang, C. R., and Stanley, B. G. (2014). Activation of lateral hypothalamic mGlul and mGlu5 receptors elicits feeding in rats. Neuropharmacology 79, 59-65. doi: 10.1016/j.neuropharm.2013. 10.033

Chee, S.-S. A., and Menard, J. L. (2011). Lesions of the dorsal lateral septum do not affect neophagia in the novelty induced suppression of feeding paradigm but reduce defensive behaviours in the elevated plus maze and shock probe burying tests. Behav. Brain Res. 220, 362-366. doi: 10.1016/j.bbr.2011.02.027

Chee, S.-S. A., and Menard, J. L. (2013). The histaminergic H1, H2 and H3 receptors of the lateral septum differentially mediate the anxiolytic-like effects of histamine on rats' defensive behaviors in the elevated plus maze and noveltyinduced suppression of feeding paradigm. Physiol. Behav. 116-117, 66-74. doi: 10.1016/j.physbeh.2013.03.016

Chen, Y.-W., Rada, P. V., Bützler, B. P., Leibowitz, S. F., and Hoebel, B. G. (2012b). Corticotropin-releasing factor in the nucleus accumbens shell induces swim depression, anxiety and anhedonia along with changes in local dopamine/acetylcholine balance. Neuroscience 206, 155-166. doi: 10.1016/j. neuroscience.2011.12.009

Chen, S., and Su, H.-S. (1990). Afferent connections of the thalamic paraventricular and parataenial nuclei in the rat-a retrograde tracing study with iontophoretic application of Fluoro-Gold. Brain Res. 522, 1-6. doi: 10. 1016/0006-8993(90)91570-7

Choi, D. L., Davis, J. F., Fitzgerald, M. E., and Benoit, S. C. (2010). The role of orexin-A in food motivation, reward-based feeding behavior and foodinduced neuronal activation in rats. Neuroscience 167, 11-20. doi: 10.1016/j. neuroscience.2010.02.002

Choi, D. L., Davis, J. F., Magrisso, I. J., Fitzgerald, M. E., Lipton, J. W., and Benoit, S. C. (2012). Orexin signaling in the paraventricular thalamic nucleus modulates mesolimbic dopamine and hedonic feeding in the rat. Neuroscience 210, 243 248. doi: 10.1016/j.neuroscience.2012.02.036

Chou, T. C., Lee, C. E., Lu, J., Elmquist, J. K., Hara, J., Willie, J. T., et al. (2001). Orexin (hypocretin) neurons contain dynorphin. J. Neurosci. 21:RC168.

Christie, M. J., James, L. B., and Beart, P. M. (1985). An excitant amino acid projection from the medial prefrontal cortex to the anterior part of nucleus accumbens in the rat. J. Neurochem. 45, 477-482. doi: 10.1111/j.1471-4159.1985. tb04013.x

Christie, M. J., Summers, R. J., Stephenson, J. A., Cook, C. J., and Beart, P. M. (1987). Excitatory amino acid projections to the nucleus accumbens septi in the rat: a retrograde transport study utilizingd $[3 \mathrm{H}]$ aspartate and $[3 \mathrm{H}] \mathrm{GABA}$. Neuroscience 22, 425-439. doi: 10.1016/0306-4522(87)90345-9

Chronwall, B. M., DiMaggio, D. A., Massari, V. J., Pickel, V. M., Ruggiero, D. A., and O'Donohue, T. L. (1985). The anatomy of neuropeptide-y-containing neurons in rat brain. Neuroscience 15, 1159-1181. doi: 10.1016/0306-4522(85)90260-x

Churchill, L., and Kalivas, P. W. (1994). A topographically organized gammaaminobutyric acid projection from the ventral pallidum to the nucleus accumbens in the rat. J. Comp. Neurol. 345, 579-595. doi: 10.1002/cne. 903450408

Conn, P. J., and Pin, J.-P. (1997). Pharmacology and functions of metabotropic glutamate receptors. Annu. Rev. Pharmacol. Toxicol. 37, 205-237. doi: 10. 1146/annurev.pharmtox.37.1.205

Covelo, I. R., Patel, Z. I., Luviano, J. A., Stratford, T. R., and Wirtshafter, D. (2014). Manipulation of GABA in the ventral pallidum, but not the nucleus accumbens, induces intense, preferential, fat consumption in rats. Behav. Brain Res. 270, 316-325. doi: 10.1016/j.bbr.2014.05.032

Cromwell, H. C., and Berridge, K. C. (1993). Where does damage lead to enhanced food aversion: the ventral pallidum/substantia innominata or lateral hypothalamus? Brain Res. 624, 1-10. doi: 10.1016/0006-8993(93)90053-p

Cullinan, W. E., and Záborszky, L. (1991). Organization of ascending hypothalamic projections to the rostral forebrain with special reference to the innervation of cholinergic projection neurons. J. Comp. Neurol. 306, 631-667. doi: 10.1002/cne. 903060408

de Gortari, P., Mancera, K., Cote-Vélez, A., Amaya, M. I., Martínez, A., Jaimes-Hoy, L., et al. (2009). Involvement of CRH-R2 receptor in eating behavior and in the response of the HPT axis in rats subjected to dehydration-induced anorexia. Psychoneuroendocrinology 34, 259-272. doi: 10.1016/j.psyneuen.2008.09.010

Deller, T., Leranth, C., and Frotscher, M. (1994). Reciprocal connections of lateral septal neurons and neurons in the lateral hypothalamus in the rat: a combined phaseolus vulgaris-leucoagglutinin and Fluoro-Gold immunocytochemical study. Neurosci. Lett. 168, 119-122. doi: 10.1016/0304-3940(94)90430-8

Ding, Y. Q., Kaneko, T., Nomura, S., and Mizuno, N. (1996). Immunohistochemical localization of mu-opioid receptors in the central nervous system of the rat. J. Comp. Neurol. 367, 375-402. doi: 10.1002/(SICI)10969861(19960408)367:3<375::AID-CNE5>3.0.CO;2-2

Duva, M. A., Tomkins, E. M., Moranda, L. M., Kaplan, R., Sukhaseum, A., Bernardo, J. P., et al. (2002). Regional differences in feeding and other behaviors elicited by $\mathrm{N}$-methyl-D-aspartic acid in the rodent hypothalamus: a reverse microdialysis mapping study. Brain Res. 925, 141-147. doi: 10.1016/s00068993(01)03269-3

Duva, M. A., Tomkins, E. M., Moranda, L. M., Kaplan, R., Sukhaseum, A., and Stanley, B. G. (2005). Origins of lateral hypothalamic afferents associated with $\mathrm{N}$-methyl-d-aspartic acid-elicited eating studied using reverse microdialysis of NMDA and Fluorogold. Neurosci. Res. 52, 95-106. doi: 10.1016/j.neures.2005. 02.001

Elias, C. F., Sita, L. V., Zambon, B. K., Oliveira, E. R., Vasconcelos, L. A. P., and Bittencourt, J. C. (2008). Melanin-concentrating hormone projections to areas 
involved in somatomotor responses. J. Chem. Neuroanat. 35, 188-201. doi: 10. 1016/j.jchemneu.2007.10.002

Fadel, J., and Deutch, A. Y. (2002). Anatomical substrates of orexin-dopamine interactions: lateral hypothalamic projections to the ventral tegmental area. Neuroscience 111, 379-387. doi: 10.1016/s0306-4522(02)00017-9

Fallon, J. H., and Leslie, F. M. (1986). Distribution of dynorphin and enkephalin peptides in the rat brain. J. Comp. Neurol. 249, 293-336. doi: 10.1002/cne. 902490302

Farrar, A. M., Font, L., Pereira, M., Mingote, S., Bunce, J. G., Chrobak, J. J., et al. (2008). Forebrain circuitry involved in effort-related choice: injections of the GABAA agonist muscimol into ventral pallidum alter response allocation in food-seeking behavior. Neuroscience 152, 321-330. doi: 10.1016/j.neuroscience. 2007.12.034

Faure, A., Richard, J. M., and Berridge, K. C. (2010). Desire and dread from the nucleus accumbens: cortical glutamate and subcortical GABA differentially generate motivation and hedonic impact in the rat. PLoS One 5:e11223. doi: 10. 1371/journal.pone.0011223

Flegal, K. M., Carroll, M. D., Ogden, C. L., and Johnson, C. L. (2002). Prevalence and trends in obesity among US adults, 1999-2000. JAMA 288, 1723-1727. doi: 10.1001/jama.288.14.1723

Flynn, F. W., Evey, L. A., Steele, T. L., and Mitchell, J. C. (1986). The relation of feeding and activity following septal lesions in rats. Behav. Neurosci. 100, 416421. doi: 10.1037//0735-7044.100.3.416

George, S. R., Zastawny, R. L., Briones-Urbina, R., Cheng, R., Nguyen, T., Heiber, M., et al. (1994). Distinct distributions of mu, delta and kappa opioid receptor mRNA in rat brain. Biochem. Biophys. Res. Commun. 205, 1438-1444. doi: 10. 1006/bbrc. 1994.2826

Georgescu, D., Sears, R. M., Hommel, J. D., Barrot, M., Bolaños, C. A., Marsh, D. J., et al. (2005). The hypothalamic neuropeptide melanin-concentrating hormone acts in the nucleus accumbens to modulate feeding behavior and forced-swim performance. J. Neurosci. 25, 2933-2940. doi: 10.1523/jneurosci.1714-04.2005

Goebel, M., Stengel, A., Lambrecht, N. W. G., Wang, L., and Tache, Y. (2009). Nesfatin-1 immunoreactivity in rat brain and spinal cord autonomic nuclei. Neurosci. Lett. 452, 241-246. doi: 10.1016/j.neulet.2009.01.064

Gong, Y., Xu, L., Guo, F., Pang, M., Shi, Z., Gao, S., et al. (2014). Effects of ghrelin on gastric distension sensitive neurons and gastric motility in the lateral septum and arcuate nucleus regulation. J. Gastroenterol. 49, 219-230. doi: 10.1007/s00535013-0789-y

Goto, M., Canteras, N. S., Burns, G., and Swanson, L. W. (2005). Projections from the subfornical region of the lateral hypothalamic area. J. Comp. Neurol. 493, 412-438. doi: 10.1002/cne.20764

Groenewegen, H. J., Berendse, H. W., and Haber, S. N. (1993). Organization of the output of the ventral striatopallidal system in the rat: ventral pallidal efferents. Neuroscience 57, 113-142. doi: 10.1016/0306-4522(93)90115-v

Gu, G., Lorrain, D. S., Wei, H., Cole, R. L., Zhang, X., Daggett, L. P., et al. (2008). Distribution of metabotropic glutamate 2 and 3 receptors in the rat forebrain: implication in emotional responses and central disinhibition. Brain Res. 1197, 47-62. doi: 10.1016/j.brainres.2007.12.057

Haber, S. N., Groenewegen, H. J., Grove, E. A., and Nauta, W. J. (1985). Efferent connections of the ventral pallidum: evidence of a dual striato pallidofugal pathway. J. Comp. Neurol. 235, 322-335. doi: 10.1002/cne.902350304

Hahn, J. D. (2010). Comparison of melanin-concentrating hormone and hypocretin/orexin peptide expression patterns in a current parceling scheme of the lateral hypothalamic zone. Neurosci. Lett. 468, 12-17. doi: 10.1016/j.neulet. 2009.10.047

Hahn, J. D., and Swanson, L. W. (2010). Distinct patterns of neural inputs and outputs of the juxtaparaventricular and suprafornical regions of the lateral hypothalamic area in the male rat. Brain Res. Rev. 64, 14-103. doi: 10.1016/j. brainresrev.2010.02.002

Hâkansson, M. L., Brown, H., Ghilardi, N., Skoda, R. C., and Meister, B. (1998). Leptin receptor immunoreactivity in chemically defined target neurons of the hypothalamus. J. Neurosci. 18, 559-572.

Harlan, R. E., Shivers, B. D., Romano, G. J., Pfaff, D. W., and Howells, R. D. (1987). Localization of preproenkephalin mRNA in the rat brain and spinal cord by in situ hybridization. J. Comp. Neurol. 258, 159-184. doi: 10.1002/cne.9025 80202

Harris, G. C., Wimmer, M., and Aston-Jones, G. (2005). A role for lateral hypothalamic orexin neurons in reward seeking. Nature 437, 556-559. doi: 10. 1038/nature04071
Heydendael, W., Sharma, K., Iyer, V., Luz, S., Piel, D., Beck, S., et al. (2011). Orexins/hypocretins act in the posterior paraventricular thalamic nucleus during repeated stress to regulate facilitation to novel stress. Endocrinology 152, 4738-4752. doi: 10.1210/en.2011-1652

Ho, C.-Y., and Berridge, K. C. (2013). An orexin hotspot in ventral pallidum amplifies hedonic "liking" for sweetness. Neuropsychopharmacology 38, 16551664. doi: $10.1038 / \mathrm{npp} .2013 .62$

Ho, C.-Y., and Berridge, K. C. (2014). Excessive disgust caused by brain lesions or temporary inactivations: mapping hotspots of the nucleus accumbens and ventral pallidum. Eur. J. Neurosci. 40, 3556-3572. doi: 10.1111/ejn.12720

Hoebel, B. G., Avena, N. M., and Rada, P. (2007). Accumbens dopamineacetylcholine balance in approach and avoidance. Curr. Opin. Pharmacol. 7, 617-627. doi: 10.1016/j.coph.2007.10.014

Holahan, M. R., Kalin, N. H., and Kelley, A. E. (1997). Microinfusion of corticotropin-releasing factor into the nucleus accumbens shell results in increased behavioral arousal and oral motor activity. Psychopharmacology (Berl) 130, 189-196. doi: 10.1007/s002130050228

Hsu, D. T., and Price, J. L. (2009). The paraventricular thalamic nucleus: subcortical connections and innervation by serotonin, orexin and corticotropin-releasing hormone in macaque monkeys. J. Comp. Neurol. 512, 825-848. doi: 10.1002/cne. 21934

Hur, E. E., and Zaborszky, L. (2005). Vglut2 afferents to the medial prefrontal and primary somatosensory cortices: a combined retrograde tracing in situ hybridization. J. Comp. Neurol. 483, 351-373. doi: 10.1002/cne.20444

Igelstrom, K. M., Herbison, A. E., and Hyland, B. I. (2010). Enhanced c-Fos expression in superior colliculus, paraventricular thalamus and septum during learning of cue-reward association. Neuroscience 168, 706-714. doi: 10.1016/j. neuroscience.2010.04.018

Ishibashi, M., Takano, S., Yanagida, H., Takatsuna, M., Nakajima, K., Oomura, Y., et al. (2005). Effects of orexins/hypocretins on neuronal activity in the paraventricular nucleus of the thalamus in rats in vitro. Peptides 26, 471-481. doi: 10.1016/j.peptides.2004.10.014

Janzsó, G., Valcz, G., Thuma, Á., Szóke, B., Lendvai, Z., Ábrahám, H., et al. (2010). Cocaine- and amphetamine-regulated transcript (CART) peptideimmunopositive neuronal elements in the lateral septum: rostrocaudal distribution in the male rat. Brain Res. 1362, 40-47. doi: 10.1016/j.brainres.2010. 09.079

Jiménez, A., Caba, M., and Escobar, C. (2013). Food-entrained patterns in orexin cells reveal subregion differential activation. Brain Res. 1513, 41-50. doi: 10. 1016/j.brainres.2013.03.031

Johnson, N., and Pasternak, G. W. (1983). The binding to rat brain homogenates of Mr2034, a universal opiate. Life Sci. 33, 985-991. doi: 10.1016/00243205(83)90755-5

Jones, D. L., and Mogenson, G. J. (1980). Nucleus accumbens to globus pallidus GABA projection: electrophysiological and iontophoretic investigations. Brain Res. 188, 93-105. doi: 10.1016/0006-8993(80)90559-4

Kahn, L., Alonso, G., Robbe, D., Bockaert, J., and Manzoni, O. J. (2001). Group 2 metabotropic glutamate receptors induced long term depression in mouse striatal slices. Neurosci. Lett. 316, 178-182. doi: 10.1016/s0304-3940(01)02397-7

Kampe, J., Tschöp, M. H., Hollis, J. H., and Oldfield, B. J. (2009). An anatomic basis for the communication of hypothalamic, cortical and mesolimbic circuitry in the regulation of energy balance. Eur. J. Neurosci. 30, 415-430. doi: 10.1111/j. 1460-9568.2009.06818.x

Kelley, A. E., Bakshi, V. P., Haber, S. N., Steininger, T. L., Will, M. J., and Zhang, M. (2002). Opioid modulation of taste hedonics within the ventral striatum. Physiol. Behav. 76, 365-377. doi: 10.1016/s0031-9384(02)00751-5

Kelley, A. E., Baldo, B. A., and Pratt, W. E. (2005b). A proposed hypothalamicthalamic-striatal axis for the integration of energy balance, arousal and food reward. J. Comp. Neurol. 493, 72-85. doi: 10.1002/cne.20769

Kelley, A. E., Baldo, B. A., Pratt, W. E., and Will, M. J. (2005a). Corticostriatalhypothalamic circuitry and food motivation: integration of energy, action and reward. Physiol. Behav. 86, 773-795. doi: 10.1016/j.physbeh.2005.08.066

Khan, A. M. (2013). Controlling feeding behavior by chemical or gene-directed targeting in the brain: what's so spatial about our methods? Front. Neurosci. 7:182. doi: $10.3389 /$ fnins.2013.00182

Kirouac, G. J., Parsons, M. P., and Li, S. (2006). Innervation of the paraventricular nucleus of the thalamus from cocaine- and amphetamine-regulated transcript (CART) containing neurons of the hypothalamus. J. Comp. Neurol. 497, 155165. doi: 10.1002/cne.20971 
Kolaj, M., Zhang, L., Hermes, M.L.H.J., and Renaud, L. P. (2014). Intrinsic properties and neuropharmacology of midline paraventricular thalamic nucleus neurons. Front. Behav. Neurosci. 8:132. doi: 10.3389/fnbeh.2014.00132

Kovács, E. G., Szalay, F., and Halasy, K. (2005). Fasting-induced changes of neuropeptide immunoreactivity in the lateral septum of male rats. Acta Biol. Hung. 56, 185-197. doi: 10.1556/abiol.56.2005.3-4.2

Kovács, É. G., Szalay, F., Rácz, B., and Halasy, K. (2007). Chronic fasting-induced changes of neuropeptide $\mathrm{Y}$ immunoreactivity in the lateral septum of intact and ovariectomized female rats. Brain Res. 1153, 103-110. doi: 10.1016/j.brainres. 2007.03.064

Krause, M., German, P. W., Taha, S. A., and Fields, H. L. (2010). A pause in nucleus accumbens neuron firing is required to initiate and maintain feeding. J. Neurosci. 30, 4746-4756. doi: 10.1523/JNEUROSCI.0197-10.2010

Kupchik, Y. M., and Kalivas, P. W. (2013). The rostral subcommissural ventral pallidum is a mix of ventral pallidal neurons and neurons from adjacent areas: an electrophysiological study. Brain Struct. Funct. 218, 1487-1500. doi: 10. 1007/s00429-012-0471-9

Kupchik, Y. M., Scofield, M. D., Rice, K. C., Cheng, K., Roques, B. P., and Kalivas, P. W. (2014). Cocaine dysregulates opioid gating of GABA neurotransmission in the ventral pallidum. J. Neurosci. 34, 1057-1066. doi: 10.1523/JNEUROSCI. 4336-13.2014

Kurose, T., Ueta, Y., Yamamoto, Y., Serino, R., Ozaki, Y., Saito, J., et al. (2002). Effects of restricted feeding on the activity of hypothalamic Orexin (OX)A containing neurons and OX2 receptor mRNA level in the paraventricular nucleus of rats. Regul. Pept. 104, 145-151. doi: 10.1016/s0167-0115(01) 00340-8

Lape, R., and Dani, J. A. (2004). Complex response to afferent excitatory bursts by nucleus accumbens medium spiny projection neurons. J. Neurophysiol. 92, 1276-1284. doi: 10.1152/jn.00066.2004

Laque, A., Zhang, Y., Gettys, S., Nguyen, T.-A., Bui, K., Morrison, C. D., et al. (2013). Leptin receptor neurons in the mouse hypothalamus are colocalized with the neuropeptide galanin and mediate anorexigenic leptin action. Am. J. Physiol. Endocrinol. Metab. 304, E999-E1011. doi: 10.1152/ajpendo.00643.2012

Lee, J. S., Lee, E. Y., and Lee, H. S. (2014). Hypothalamic, feeding/arousal-related peptidergic projections to the paraventricular thalamic nucleus in the rat. Brain Res. doi: 10.1016/j.brainres.2014.12.029. [Epub ahead of print].

Leibowitz, S. F., and Rossakis, C. (1978). Pharmacological characterization of perifornical hypothalamic $\beta$-adrenergic receptors mediating feeding inhibition in the rat. Neuropharmacology 17, 691-702. doi: 10.1016/0028-3908(78)90082-5

Leibowitz, S. F., and Rossakis, C. (1979). Pharmacological characterization of perifornical hypothalamic dopamine receptors mediating feeding inhibition in the rat. Brain Res. 172, 115-130. doi: 10.1016/0006-8993(79)90899-0

Lemos, J. C., Wanat, M. J., Smith, J. S., Reyes, B. A. S., Hollon, N. G., Van Bockstaele, E. J., et al. (2012). Severe stress switches CRF action in the nucleus accumbens from appetitive to aversive. Nature 490, 402-406. doi: 10.1038/nature11436

Li, F. W., Deurveilher, S., and Semba, K. (2011). Behavioural and neuronal activation after microinjections of AMPA and NMDA into the perifornical lateral hypothalamus in rats. Behav. Brain Res. 224, 376-386. doi: 10.1016/j.bbr. 2011.06.021

Li, S., and Kirouac, G. J. (2008). Projections from the paraventricular nucleus of the thalamus to the forebrain, with special emphasis on the extended amygdala. J. Comp. Neurol. 506, 263-287. doi: 10.1002/cne.21502

Li, S., and Kirouac, G. J. (2012). Sources of inputs to the anterior and posterior aspects of the paraventricular nucleus of the thalamus. Brain Struct. Funct. 217, 257-273. doi: 10.1007/s00429-011-0360-7

Ligorio, M., Descarries, L., and Warren, R. A. (2009). Cholinergic innervation and thalamic input in rat nucleus accumbens. J. Chem. Neuroanat. 37, 33-45. doi: 10. 1016/j.jchemneu.2008.08.003

Louis, G. W., Leinninger, G. M., Rhodes, C. J., and Myers, M. G. (2010). Direct innervation and modulation of orexin neurons by lateral hypothalamic LepRb neurons. J. Neurosci. 30, 11278-11287. doi: 10.1523/JNEUROSCI.1340-10.2010

Maldonado-Irizarry, C. S., Swanson, C. J., and Kelley, A. E. (1995). Glutamate receptors in the nucleus accumbens shell control feeding behavior via the lateral hypothalamus. J. Neurosci. 15, 6779-6788.

Marcus, J. N., Aschkenasi, C. J., Lee, C. E., Chemelli, R. M., Saper, C. B., Yanagisawa, M., et al. (2001). Differential expression of orexin receptors 1 and 2 in the rat brain. J. Comp. Neurol. 435, 6-25. doi: 10.1002/cne.1190

Mark, G. P., Rada, P., Pothos, E., and Hoebel, B. G. (1992). Effects of feeding and drinking on acetylcholine release in the nucleus accumbens, striatum and hippocampus of freely behaving rats. J. Neurochem. 58, 2269-2274. doi: 10. 1111/j.1471-4159.1992.tb10973.x

Martin-Fardon, R., and Boutrel, B. (2012). Orexin/hypocretin (Orx/Hcrt) transmission and drug-seeking behavior: is the paraventricular nucleus of the thalamus (PVT) part of the drug seeking circuitry? Front. Behav. Neurosci. 6:75. doi: $10.3389 /$ fnbeh.2012.00075

McAlonan, G. M., Robbins, T. W., and Everitt, B. J. (1993). Effects of medial dorsal thalamic and ventral pallidal lesions on the acquisition of a conditioned place preference: further evidence for the involvement of the ventral striatopallidal system in reward-related processes. Neuroscience 52, 605-620. doi: 10.1016/0306-4522(93)90410-h

Meister, B. (2007). Neurotransmitters in key neurons of the hypothalamus that regulate feeding behavior and body weight. Physiol. Behav. 92, 263-271. doi: 10 . 1016/j.physbeh.2007.05.021

Mena, J. D., Selleck, R. A., and Baldo, B. A. (2013). Mu-opioid stimulation in rat prefrontal cortex engages hypothalamic orexin/hypocretin-containing neurons and reveals dissociable roles of nucleus accumbens and hypothalamus in cortically driven feeding. J. Neurosci. 33, 18540-18552. doi: 10. 1523/JNEUROSCI.3323-12.2013

Mendoza, J., Angeles-Castellanos, M., and Escobar, C. (2005). Differential role of the accumbens shell and core subterritories in food-entrained rhythms of rats. Behav. Brain Res. 158, 133-142. doi: 10.1016/j.bbr.2004.08.016

Meredith, G. E., and Wouterlood, F. G. (1990). Hippocampal and midline thalamic fibers and terminals in relation to the choline acetyltransferase-immunoreactive neurons in nucleus accumbens of the rat: a light and electron microscopic study. J. Comp. Neurol. 296, 204-221. doi: 10.1002/cne.902960203

Minami, M., Hosoi, Y., Toya, T., Katao, Y., Maekawa, K., Katsumata, S., et al. (1993). In situ hybridization study of kappa-opioid receptor mRNA in the rat brain. Neurosci. Lett. 162, 161-164. doi: 10.1016/0304-3940(93)90585-9

Mitra, A., Lenglos, C., Martin, J., Mbende, N., Gagné, A., and Timofeeva, E. (2011). Sucrose modifies c-fos mRNA expression in the brain of rats maintained on feeding schedules. Neuroscience 192, 459-474. doi: 10.1016/j.neuroscience.2011. 06.033

Mitrovic, I., and Napier, T. C. (1995). Electrophysiological demonstration of mu, delta and kappa opioid receptors in the ventral pallidum. J. Pharmacol. Exp. Ther. 272, 1260-1270.

Moga, M. M., Weis, R. P., and Moore, R. Y. (1995). Efferent projections of the paraventricular thalamic nucleus in the rat. J. Comp. Neurol. 359, 221-238. doi: $10.1002 /$ cne. 903590204

Mogenson, G. J., Jones, D. L., and Yim, C. Y. (1980). From motivation to action: functional interface between the limbic system and the motor system. Prog. Neurobiol. 14, 69-97. doi: 10.1016/0301-0082(80)90018-0

Mogenson, G. J., and Nielsen, M. (1984). Neuropharmacological evidence to suggest that the nucleus accumbens and subpallidal region contribute to exploratory locomotion. Behav. Neural Biol. 42, 52-60. doi: 10.1016/s01631047(84)90424-2

Mogenson, G. J., Swanson, L. W., and Wu, M. (1983). Neural projections from nucleus accumbens to globus pallidus, substantia innominata and lateral preoptic-lateral hypothalamic area: an anatomical and electrophysiological investigation in the rat. J. Neurosci. 3, 189-202.

Mora, F., Avrith, D. B., Phillips, A. G., and Rolls, E. T. (1979). Effects of satiety on self-stimulation of the orbitofrontal cortex in the rhesus monkey. Neurosci. Lett. 13, 141-145. doi: 10.1016/0304-3940(79)90031-4

Nakahara, K., Fukui, K., and Murakami, N. (2004). Involvement of thalamic paraventricular nucleus in the anticipatory reaction under food restriction in the rat. J. Vet. Med. Sci. 66, 1297-1300. doi: 10.1292/jvms.66.1297

Napier, T. C., Chrobak, J. J., and Yew, J. (1992). Systemic and microiontophoretic administration of morphine differentially effect ventral pallidum/substantia innominata neuronal activity. Synapse 12, 214-219. doi: 10.1002/syn.8901 20306

Nishimura, Y., Mabuchi, K., Taguchi, S., Ikeda, S., Aida, E., Negishi, H., et al. (2014). Involvement of orexin-A neurons but not melanin-concentrating hormone neurons in the short-term regulation of food intake in rats. J. Physiol. Sci. 64, 203-211. doi: 10.1007/s12576-014-0312-0

Novak, C. M., and Nunez, A. A. (1998). Daily rhythms in Fos activity in the rat ventrolateral preoptic area and midline thalamic nuclei. Am. J. Physiol. 275, R1620-R1626.

Obukuro, K., Takigawa, M., Hisatsune, A., Isohama, Y., and Katsuki, H. (2010). Quinolinate induces selective loss of melanin-concentrating hormone neurons, 
rather than orexin neurons, in the hypothalamus of mice and young rats. Neuroscience 170, 298-307. doi: 10.1016/j.neuroscience.2010.06.081

O’Donnell, P., and Grace, A. A. (1995). Synaptic interactions among excitatory afferents to nucleus accumbens neurons: hippocampal gating of prefrontal cortical input. J. Neurosci. 15, 3622-3639.

O’Donnell, P., Greene, J., Pabello, N., Lewis, B. L., and Grace, A. A. (1999), Modulation of cell firing in the nucleus accumbens. Ann. N Y Acad. Sci. 877, 157-175. doi: 10.1111/j.1749-6632.1999.tb09267.x

Oertel, W. H., and Mugnaini, E. (1984). Immunocytochemical studies of GABAergic neurons in rat basal ganglia and their relations to other neuronal systems. Neurosci. Lett. 47, 233-238. doi: 10.1016/0304-3940(84)90519-6

Olszewski, P. K., Shaw, T. J., Grace, M. K., Höglund, C. E., Fredriksson, R., Schiöth, H. B., et al. (2009). Complexity of neural mechanisms underlying overconsumption of sugar in scheduled feeding: involvement of opioids, orexin, oxytocin and NPY. Peptides 30, 226-233. doi: 10.1016/j.peptides.2008.10.011

Oomura, Y., Ooyama, H., Sugimori, M., Nakamura, T., and Yamada, Y. (1974). Glucose inhibition of the glucose-sensitive neurone in the rat lateral hypothalamus. Nature 247, 284-286. doi: 10.1038/247284a0

Otake, K., and Nakamura, Y. (1995). Sites of origin of corticotropin-releasing factor-like immunoreactive projection fibers to the paraventricular thalamic nucleus in the rat. Neurosci. Lett. 201, 84-86. doi: 10.1016/0304-3940(95) 12148-w

Otake, K., and Nakamura, Y. (1998). Single midline thalamic neurons projecting to both the ventral striatum and the prefrontal cortex in the rat. Neuroscience 86, 635-649. doi: 10.1016/s0306-4522(98)00062-1

Panagis, G., Nomikos, G. G., Miliaressis, E., Chergui, K., Kastellakis, A., Svensson, T. H., et al. (1997). Ventral pallidum self-stimulation induces stimulus dependent increase in c-fos expression in reward-related brain regions. Neuroscience 77, 175-186. doi: 10.1016/s0306-4522(96)00471-x

Park, T. H., and Carr, K. D. (1998). Neuroanatomical patterns of fos-like immunoreactivity induced by a palatable meal and meal-paired environment in saline- and naltrexone-treated rats. Brain Res. 805, 169-180. doi: 10.1016/s00068993(98)00719-7

Parsons, M. P., Li, S., and Kirouac, G. J. (2006). The paraventricular nucleus of the thalamus as an interface between the orexin and CART peptides and the shell of the nucleus accumbens. Synapse 59, 480-490. doi: 10.1002/syn.20264

Patterson, C. M., Leshan, R. L., Jones, J. C., and Myers, M. G. Jr. (2011). Molecular mapping of mouse brain regions innervated by leptin receptor-expressing cells. Brain Res. 1378, 18-28. doi: 10.1016/j.brainres.2011.01.010

Patyal, R., Woo, E. Y., and Borgland, S. L. (2012). Local hypocretin-1 modulates terminal dopamine concentration in the nucleus accumbens shell. Front. Behav. Neurosci. 6:82. doi: 10.3389/fnbeh.2012.00082

Paxinos, G., and Watson, C. (2013). The Rat Brain in Stereotaxic Coordinates. 7th Edn. Amsterdam; Boston: Academic Press.

Peciña, S., and Berridge, K. C. (2005). Hedonic hot spot in nucleus accumbens shell: where do mu-opioids cause increased hedonic impact of sweetness? J. Neurosci. 25, 11777-11786. doi: 10.1523/jneurosci.2329-05.2005

Peciña, S., Schulkin, J., and Berridge, K. C. (2006). Nucleus accumbens corticotropin-releasing factor increases cue-triggered motivation for sucrose reward: paradoxical positive incentive effects in stress? BMC Biol. 4:8. doi: 10. 1186/1741-7007-4-8

Phillipson, O. T., and Griffiths, A. C. (1985). The topographic order of inputs to nucleus accumbens in the rat. Neuroscience 16, 275-296. doi: 10.1016/03064522(85)90002-8

Pissios, P., Frank, L., Kennedy, A. R., Porter, D. R., Marino, F. E., Liu, F.-F., et al. (2008). Dysregulation of the mesolimbic dopamine system and reward in MCH/- mice. Biol. Psychiatry 64, 184-191. doi: 10.1016/j.biopsych.2007.12.011

Potter, E., Sutton, S., Donaldson, C., Chen, R., Perrin, M., Lewis, K., et al. (1994). Distribution of corticotropin-releasing factor receptor mRNA expression in the rat brain and pituitary. Proc. Natl. Acad. Sci. U S A 91, 8777-8781. doi: 10. 1073/pnas.91.19.8777

Qi, Y., Henry, B. A., Oldfield, B. J., and Clarke, I. J. (2010). The action of leptin on appetite-regulating cells in the ovine hypothalamus: demonstration of direct action in the absence of the arcuate nucleus. Endocrinology 151, 2106-2116. doi: 10.1210/en.2009-1283

Rada, P., Tucci, S., Murzi, E., and Hernández, L. (1997). Extracellular glutamate increases in the lateral hypothalamus and decreases in the nucleus accumbens during feeding. Brain Res. 768, 338-340. doi: 10.1016/s0006-8993(97) 00788-9
Ramaswamy, C., Ghosh, S., and Vasudev, R. (1998). Alteration of preference of food substances in terms of taste and nutritional value following the lesion of two subdistricts of nucleus accumbens. Indian J. Med. Res. 108, 139-144.

Reynolds, S. M., and Berridge, K. C. (2001). Fear and feeding in the nucleus accumbens shell: rostrocaudal segregation of GABA-elicited defensive behavior versus eating behavior. J. Neurosci. 21, 3261-3270.

Reynolds, S. M., and Berridge, K. C. (2002). Positive and negative motivation in nucleus accumbens shell: bivalent rostrocaudal gradients for GABA-elicited eating, taste "liking"/“disliking" reactions, place preference/avoidance and fear. J. Neurosci. 22, 7308-7320.

Reynolds, S. M., and Berridge, K. C. (2003). Glutamate motivational ensembles in nucleus accumbens: rostrocaudal shell gradients of fear and feeding. Eur. J. Neurosci. 17, 2187-2200. doi: 10.1046/j.1460-9568.2003.02642.x

Reynolds, S. M., and Berridge, K. C. (2008). Emotional environments retune the valence of appetitive versus fearful functions in nucleus accumbens. Nat. Neurosci. 11, 423-425. doi: 10.1038/nn2061

Richard, J. M., and Berridge, K. C. (2011). Metabotropic glutamate receptor blockade in nucleus accumbens shell shifts affective valence toward fear and displeasure. Eur. J. Neurosci. 33, 736-747. doi: 10.1111/j.1460-9568.2010. 07553.x

Richard, J. M., and Berridge, K. C. (2013). Prefrontal cortex modulates desire and dread generated by nucleus accumbens glutamate disruption. Biol. Psychiatry 73, 360-370. doi: 10.1016/j.biopsych.2012.08.009

Risold, P. Y., and Swanson, L. W. (1997a). Chemoarchitecture of the rat lateral septal nucleus. Brain Res. Brain Res. Rev. 24, 91-113. doi: 10.1016/s01650173(97)00008-8

Risold, P. Y., and Swanson, L. W. (1997b). Connections of the rat lateral septal complex. Brain Res. Brain Res. Rev. 24, 115-195. doi: 10.1016/s01650173(97)00009-x

Rosin, D. L., Weston, M. C., Sevigny, C. P., Stornetta, R. L., and Guyenet, P. G. (2003). Hypothalamic orexin (hypocretin) neurons express vesicular glutamate transporters VGLUT1 or VGLUT2. J. Comp. Neurol. 465, 593-603. doi: 10. 1002/cne.10860

Rossi, M., Beak, S. A., Choi, S. J., Small, C. J., Morgan, D. G., Ghatei, M. A., et al. (1999). Investigation of the feeding effects of melanin concentrating hormone on food intake-action independent of galanin and the melanocortin receptors. Brain Res. 846, 164-170. doi: 10.1016/s0006-8993(99)02005-3

Saito, Y., Cheng, M., Leslie, F. M., and Civelli, O. (2001). Expression of the melaninconcentrating hormone $(\mathrm{MCH})$ receptor mRNA in the rat brain. J. Comp. Neurol. 435, 26-40. doi: 10.1002/cne.1191

Schaefer, G. J., and Michael, R. P. (1992). Schedule-controlled brain selfstimulation: has it utility for behavioral pharmacology? Neurosci. Biobehav. Rev. 16, 569-583. doi: 10.1016/s0149-7634(05)80197-6

Schultz, W., Apicella, P., Scarnati, E., and Ljungberg, T. (1992). Neuronal activity in monkey ventral striatum related to the expectation of reward. J. Neurosci. 12, 4595-4610.

Sears, R. M., Liu, R.-J., Narayanan, N. S., Sharf, R., Yeckel, M. F., Laubach, M., et al. (2010). Regulation of nucleus accumbens activity by the hypothalamic neuropeptide melanin-concentrating hormone. J. Neurosci. 30, 8263-8273. doi: 10.1523/JNEUROSCI.5858-09.2010

Sharf, R., Sarhan, M., and DiLeone, R. J. (2010). Role of orexin/hypocretin in dependence and addiction. Brain Res. 1314, 130-138. doi: 10.1016/j.brainres. 2009.08.028

Sheehan, T. P., Chambers, R. A., and Russell, D. S. (2004). Regulation of affect by the lateral septum: implications for neuropsychiatry. Brain Res. Rev. 46, 71-117. doi: 10.1016/j.brainresrev.2004.04.009

Sherwood, A., Wosiski-Kuhn, M., Nguyen, T., Holland, P. C., Lakaye, B., Adamantidis, A., et al. (2012). The role of melanin-concentrating hormone in conditioned reward learning. Eur. J. Neurosci. 36, 3126-3133. doi: 10.1111/j. 1460-9568.2012.08207.x

Shimura, T., Imaoka, H., and Yamamoto, T. (2006). Neurochemical modulation of ingestive behavior in the ventral pallidum. Eur. J. Neurosci. 23, 1596-1604. doi: 10.1111/j.1460-9568.2006.04689.x

Siggins, G. R., Gruol, D., Aldenhoff, J., and Pittman, Q. (1985). Electrophysiological actions of corticotropin-releasing factor in the central nervous system. Fed. Proc. 44, 237-242.

Skofitsch, G., and Jacobowitz, D. M. (1985). Immunohistochemical mapping of galanin-like neurons in the rat central nervous system. Peptides 6, 509-546. doi: 10.1016/0196-9781(85)90118-4 
Smith, K. S., and Berridge, K. C. (2005). The ventral pallidum and hedonic reward: neurochemical maps of sucrose "liking" and food intake. J. Neurosci. 25, 86378649. doi: 10.1523/jneurosci.1902-05.2005

Smith, K. S., and Berridge, K. C. (2007). Opioid limbic circuit for reward: interaction between hedonic hotspots of nucleus accumbens and ventral pallidum. J. Neurosci. 27, 1594-1605. doi: 10.1523/jneurosci.4205-06.2007

Stanley, B. G., Lanthier, D., and Leibowitz, S. F. (1988). Multiple brain sites sensitive to feeding stimulation by opioid agonists: a cannula-mapping study. Pharmacol. Biochem. Behav. 31, 825-832. doi: 10.1016/0091-3057(88)90391-7

Stanley, B. G., Magdalin, W., Seirafi, A., Thomas, W. J., and Leibowitz, S. F. (1993b). The perifornical area: the major focus of (a) patchily distributed hypothalamic neuropeptide Y-sensitive feeding system(s). Brain Res. 604, 304-317. doi: 10. 1016/0006-8993(93)90382-w

Stanley, B. G., Urstadt, K. R., Charles, J. R., and Kee, T. (2011). Glutamate and GABA in lateral hypothalamic mechanisms controlling food intake. Physiol. Behav. 104, 40-46. doi: 10.1016/j.physbeh.2011.04.046

Stanley, B. G., Willett, V. L., Donias, H. W., Ha, L. H., and Spears, L. C. (1993a). The lateral hypothalamus: a primary site mediating excitatory amino acid-elicited eating. Brain Res. 630, 41-49. doi: 10.1016/0006-8993(93)90640-9

Stratford, T. R. (2005). Activation of feeding-related neural circuitry after unilateral injections of muscimol into the nucleus accumbens shell. Brain Res. 1048, $241-$ 250. doi: 10.1016/j.brainres.2005.05.002

Stratford, T. R., and Kelley, A. E. (1997). GABA in the nucleus accumbens shell participates in the central regulation of feeding behavior. J. Neurosci. 17, 44344440 .

Stratford, T. R., and Kelley, A. E. (1999). Evidence of a functional relationship between the nucleus accumbens shell and lateral hypothalamus subserving the control of feeding behavior. J. Neurosci. 19, 11040-11048.

Stratford, T. R., Kelley, A. E., and Simansky, K. J. (1999). Blockade of GABAA receptors in the medial ventral pallidum elicits feeding in satiated rats. Brain Res. 825, 199-203. doi: 10.1016/s0006-8993(99)01239-1

Stratford, T. R., Swanson, C. J., and Kelley, A. (1998). Specific changes in food intake elicited by blockade or activation of glutamate receptors in the nucleus accumbens shell. Behav. Brain Res. 93, 43-50. doi: 10.1016/s01664328(97)00140-x

Stratford, T. R., and Wirtshafter, D. (2012a). Effects of muscimol, amphetamine and DAMGO injected into the nucleus accumbens shell on food-reinforced lever pressing by undeprived rats. Pharmacol. Biochem. Behav. 101, 499-503. doi: 10. 1016/j.pbb.2012.02.010

Stratford, T. R., and Wirtshafter, D. (2012b). Evidence that the nucleus accumbens shell, ventral pallidum and lateral hypothalamus are components of a lateralized feeding circuit. Behav. Brain Res. 226, 548-554. doi: 10.1016/j.bbr.2011.10.014

Stratford, T. R., and Wirtshafter, D. (2013). Injections of muscimol into the paraventricular thalamic nucleus, but not mediodorsal thalamic nuclei, induce feeding in rats. Brain Res. 1490, 128-133. doi: 10.1016/j.brainres.2012.10.043

Swanson, L. W. (2004). Brain Maps III: Structure of the Rat Brain: An Atlas with Printed and Electronic Templates for Data, Models and Schematics. San Diego, Calif.: Academic.

Swanson, L. W., Sanchez-Watts, G., and Watts, A. G. (2005). Comparison of melanin-concentrating hormone and hypocretin/orexin mRNA expression patterns in a new parceling scheme of the lateral hypothalamic zone. Neurosci. Lett. 387, 80-84. doi: 10.1016/j.neulet.2005.06.066

Thompson, R. H., and Swanson, L. W. (2010). Hypothesis-driven structural connectivity analysis supports network over hierarchical model of brain architecture. Proc. Natl. Acad. Sci. U S A 107, 15235-15239. doi: 10.1073/pnas. 1009112107

Thorpe, A. J., and Kotz, C. M. (2005). Orexin A in the nucleus accumbens stimulates feeding and locomotor activity. Brain Res. 1050, 156-162. doi: 10. 1016/j.brainres.2005.05.045

Tindell, A. J., Berridge, K. C., and Aldridge, J. W. (2004). Ventral pallidal representation of pavlovian cues and reward: population and rate codes. J. Neurosci. 24, 1058-1069. doi: 10.1523/jneurosci.1437-03.2004

Tindell, A. J., Smith, K. S., Peciña, S., Berridge, K. C., and Aldridge, J. W. (2006). Ventral pallidum firing codes hedonic reward: when a bad taste turns good. J. Neurophysiol. 96, 2399-2409. doi: 10.1152/jn.00576.2006

Todtenkopf, M. S., Mihalakopoulos, A., and Stellar, J. R. (2002). Withdrawal duration differentially affects c-fos expression in the medial prefrontal cortex and discrete subregions of the nucleus accumbens in cocaine-sensitized rats. Neuroscience 114, 1061-1069. doi: 10.1016/s0306-4522(02)00272-5
Trivedi, P., Yu, H., MacNeil, D. J., Van der Ploeg, L. H., and Guan, X. M. (1998). Distribution of orexin receptor mRNA in the rat brain. FEBS Lett. 438, 71-75. doi: 10.1016/s0014-5793(98)01266-6

Turenius, C. I., Charles, J. R., Tsai, D. H., Ebersole, P. L., Htut, M. H., Ngo, P. T., et al. (2009a). The tuberal lateral hypothalamus is a major target for GABAA-but not GABAB-mediated control of food intake. Brain Res. 1283, 65-72. doi: 10.1016/j. brainres.2009.05.064

Turenius, C. I., Htut, M. M., Prodon, D. A., Ebersole, P. L., Ngo, P. T., Lara, R. N., et al. (2009b). GABA(A) receptors in the lateral hypothalamus as mediators of satiety and body weight regulation. Brain Res. 1262, 16-24. doi: 10.1016/j. brainres.2009.01.016

Urstadt, K. R., Coop, S. H., Banuelos, B. D., and Stanley, B. G. (2013a). Behaviorally specific versus non-specific suppression of accumbens shell-mediated feeding by ipsilateral versus bilateral inhibition of the lateral hypothalamus. Behav. Brain Res. 257, 230-241. doi: 10.1016/j.bbr.2013.09.048

Urstadt, K. R., Kally, P., Zaidi, S. F., and Stanley, B. G. (2013b). Ipsilateral feeding-specific circuits between the nucleus accumbens shell and the lateral hypothalamus: regulation by glutamate and GABA receptor subtypes. Neuropharmacology 67, 176-182. doi: 10.1016/j.neuropharm.2012.10.027

Usuda, I., Tanaka, K., and Chiba, T. (1998). Efferent projections of the nucleus accumbens in the rat with special reference to subdivision of the nucleus: biotinylated dextran amine study. Brain Res. 797, 73-93. doi: 10.1016/s00068993(98)00359-x

Van Bockstaele, E. J., and Pickel, V. M. (1995). GABA-containing neurons in the ventral tegmental area project to the nucleus accumbens in rat brain. Brain Res. 682, 215-221. doi: 10.1016/0006-8993(95)00334-m

van der Plasse, G., Schrama, R., van Seters, S. P., Vanderschuren, L. J., and Westenberg, H. G. (2012). Deep brain stimulation reveals a dissociation of consummatory and motivated behaviour in the medial and lateral nucleus accumbens shell of the rat. PLoS One 7:e33455. doi: 10.1371/journal.pone. 0033455

Vertes, R. P., and Hoover, W. B. (2008). Projections of the paraventricular and paratenial nuclei of the dorsal midline thalamus in the rat. J. Comp. Neurol. 508, 212-237. doi: 10.1002/cne.21679

Vong, L., Ye, C., Yang, Z., Choi, B., Chua, S., and Lowell, B. B. (2011). Leptin action on GABAergic neurons prevents obesity and reduces inhibitory tone to POMC neurons. Neuron 71, 142-154. doi: 10.1016/j.neuron.2011.05.028

Walaas, I., and Fonnum, F. (1979). The distribution and origin of glutamate decarboxylase and choline acetyltransferase in ventral pallidum and other basal forebrain regions. Brain Res. 177, 325-336. doi: 10.1016/0006-8993(79)90783-2

Walaas, I., and Fonnum, F. (1980). Biochemical evidence for glutamate as a transmitter in hippocampal efferents to the basal forebrain and hypothalamus in the rat brain. Neuroscience 5, 1691-1698. doi: 10.1016/0306-4522(80)90088-3

Warne, J. P., Horneman, H. F., Ginsberg, A. B., Pecoraro, N. C., Foster, M. T., Akana, S. F., et al. (2007). Mapping brain c-Fos immunoreactivity after insulin-induced voluntary lard intake: insulin- and lard-associated patterns. J. Neuroendocrinol. 19, 794-808. doi: 10.1111/j.1365-2826.2007.01593.x

Watts, A. G., Sanchez-Watts, G., and Kelly, A. B. (1999). Distinct patterns of neuropeptide gene expression in the lateral hypothalamic area and arcuate nucleus are associated with dehydration-induced anorexia. J. Neurosci. 19, 61116121.

Will, M. J., Vanderheyden, W. M., and Kelley, A. E. (2007). Striatal opioid peptide gene expression differentially tracks short-term satiety but does not vary with negative energy balance in a manner opposite to hypothalamic NPY. Am. J. Physiol. Regul. Integr. Comp. Physiol. 292, R217-R226. doi: 10.1152/ajpregu. 00852.2005

Winn, P., Tarbuck, A., and Dunnett, S. B. (1984). Ibotenic acid lesions of the lateral hypothalamus: comparison with the electrolytic lesion syndrome. Neuroscience 12, 225-240. doi: 10.1016/0306-4522(84)90149-0

Wirtshafter, D., and Stratford, T. R. (2010). Evidence for motivational effects elicited by activation of GABA-A or dopamine receptors in the nucleus accumbens shell. Pharmacol. Biochem. Behav. 96, 342-346. doi: 10.1016/j.pbb. 2010.06.004

Wise, R. A. (2013). Dual roles of dopamine in food and drug seeking: the drivereward paradox. Biol. Psychiatry 73, 819-826. doi: 10.1016/j.biopsych.2012.09. 001

Wyrwicka, W., and Dobrzecka, C. (1960). Relationship between feeding and satiation centers of the hypothalamus. Science 132, 805-806. doi: 10 . 1126/science.132.3430.805 
Xi, Z.-X., Baker, D. A., Shen, H., Carson, D. S., and Kalivas, P. W. (2002). Group II metabotropic glutamate receptors modulate extracellular glutamate in the nucleus accumbens. J. Pharmacol. Exp. Ther. 300, 162-171. doi: 10.1124/jpet. 300.1.162

Yamanaka, A., Beuckmann, C. T., Willie, J. T., Hara, J., Tsujino, N., Mieda, M., et al. (2003). Hypothalamic orexin neurons regulate arousal according to energy balance in mice. Neuron 38, 701-713. doi: 10.1016/s0896-6273(03)00331-3

Yang, S.-C., Shieh, K.-R., and Li, H.-Y. (2005). Cocaine- and amphetamineregulated transcript in the nucleus accumbens participates in the regulation of feeding behavior in rats. Neuroscience 133, 841-851. doi: 10.1016/j.neuroscience. 2005.03.023

Yoshida, K., McCormack, S., España, R. A., Crocker, A., and Scammell, T. E. (2006). Afferents to the orexin neurons of the rat brain. J. Comp. Neurol. 494, 845-861. doi: 10.1002/cne.20859

Zahm, D. S. (1989). The ventral striatopallidal parts of the basal ganglia in the rat-II. Compartmentation of ventral pallidal efferents. Neuroscience 30, 33-50. doi: 10.1016/0306-4522(89)90351-5

Zahm, D. S., Parsley, K. P., Schwartz, Z. M., and Cheng, A. Y. (2013). On lateral septum-like characteristics of outputs from the accumbal hedonic "hotspot" of Peciña and Berridge with commentary on the transitional nature of basal forebrain "boundaries". J. Comp. Neurol. 521, 50-68. doi: 10.1002/cne.23157

Zahm, D. S., Williams, E., and Wohltmann, C. (1996). Ventral striatopallidothalamic projection: IV. Relative involvements of neurochemically distinct subterritories in the ventral pallidum and adjacent parts of the rostroventral forebrain. J. Comp. Neurol. 364, 340-362. doi: 10.1002/(sici)10969861(19960108)364:2<340::aid-cne11>3.0.co;2-t

Zhang, M., Gosnell, B. A., and Kelley, A. E. (1998). Intake of high-fat food is selectively enhanced by mu opioid receptor stimulation within the nucleus accumbens. J. Pharmacol. Exp. Ther. 285, 908-914.

Zhao, C., Eisinger, B., and Gammie, S. C. (2013). Characterization of GABAergic neurons in the mouse lateral septum: a double fluorescence in situ hybridization and immunohistochemical study using tyramide signal amplification. PLoS One 8:e73750. doi: 10.1371/journal.pone.0073750

Zheng, H., Corkern, M. M., Crousillac, S. M., Patterson, L. M., Phifer, C. B., and Berthoud, H.-R. (2002). Neurochemical phenotype of hypothalamic neurons showing Fos expression $23 \mathrm{~h}$ after intracranial AgRP. Am. J. Physiol. Regul. Integr. Comp. Physiol. 282, R1773-R1781. doi: 10.1152/ajpregu.00019.2002

Zheng, H., Corkern, M., Stoyanova, I., Patterson, L. M., Tian, R., and Berthoud, H.-R. (2003). Peptides that regulate food intake: appetite-inducing accumbens manipulation activates hypothalamic orexin neurons and inhibits POMC neurons. Am. J. Physiol. Regul. Integr. Comp. Physiol. 284, R1436-R1444. doi: 10. 1152/ajpregu.00781.2002

Zhu, Y., Yamanaka, A., Kunii, K., Tsujino, N., Goto, K., and Sakurai, T. (2002). Orexin-mediated feeding behavior involves both leptin-sensitive and -insensitive pathways. Physiol. Behav. 77, 251-257. doi: 10.1016/s00319384(02)00843-0

Conflict of Interest Statement: The authors declare that the research was conducted in the absence of any commercial or financial relationships that could be construed as a potential conflict of interest.

Received: 30 July 2014; accepted: 15 January 2015; published online: 13 February 2015. Citation: Urstadt KR and Stanley BG (2015) Direct hypothalamic and indirect transpallidal, trans-thalamic, or trans-septal control of accumbens signaling and their roles in food intake. Front. Syst. Neurosci. 9:8. doi: 10.3389/fnsys.2015.00008

This article was submitted to the journal Frontiers in Systems Neuroscience. Copyright (c) 2015 Urstadt and Stanley. This is an open-access article distributed under the terms of the Creative Commons Attribution License (CC BY). The use, distribution and reproduction in other forums is permitted, provided the original author(s) or licensor are credited and that the original publication in this journal is cited, in accordance with accepted academic practice. No use, distribution or reproduction is permitted which does not comply with these terms. 